\title{
Review \\ Review of Therapeutic Strategies for Anaplastic Lymphoma Kinase-Rearranged Non-Small Cell Lung Cancer
}

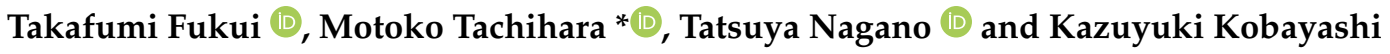

\begin{abstract}
Division of Respiratory Medicine, Department of Internal Medicine, Kobe University Graduate School of Medicine, Kobe 650-0017, Hyogo, Japan; takafumi_04garnet91@icloud.com (T.F.); tnagano@med.kobe-u.ac.jp (T.N.); kkoba@med.kobe-u.ac.jp (K.K.)

* Correspondence: mt0318@med.kobe-u.ac.jp; Tel.: +81-78-382-5660
\end{abstract}

check for updates

Citation: Fukui, T.; Tachihara, M.; Nagano, T.; Kobayashi, K. Review of Therapeutic Strategies for Anaplastic Lymphoma Kinase-Rearranged Non-Small Cell Lung Cancer. Cancers 2022, 14, 1184. https://doi.org/ 10.3390/cancers14051184

Academic Editor: Francesco Petrella

Received: 28 December 2021

Accepted: 23 February 2022

Published: 24 February 2022

Publisher's Note: MDPI stays neutral with regard to jurisdictional claims in published maps and institutional affiliations.

Copyright: (C) 2022 by the authors. Licensee MDPI, Basel, Switzerland. This article is an open access article distributed under the terms and conditions of the Creative Commons Attribution (CC BY) license (https:// creativecommons.org/licenses/by/ $4.0 /)$.
Simple Summary: Anaplastic lymphoma kinase (ALK)-rearranged non-small cell lung cancer (NSCLC) was first reported in 2007. Following the development of crizotinib as a tyrosine kinase inhibitor (TKI) targeting ALK, the treatment of advanced NSCLC with ALK-rearrangements has made remarkable progress. Currently, there are five ALK-TKIs approved by the FDA, and the development of new agents, including fourth-generation TKI, is ongoing. Clinical trials with angiogenesis inhibitors and immune checkpoint inhibitors are also underway, and further progress in the treatment of ALK-rearranged advanced NSCLC is expected. The purpose of this manuscript is to provide information on the recent clinical trials of ALK-TKIs, angiogenesis inhibitors, immune checkpoint inhibitors, and chemotherapy, to describe tissue and liquid biopsy as a method to investigate the mechanisms of resistance against ALK-TKIs and suggest a proposed treatment algorithm.

Abstract: Non-small cell lung cancer (NSCLC) with anaplastic lymphoma kinase rearrangement (ALK) was first reported in 2007. ALK-rearranged NSCLC accounts for about 3-8\% of NSCLC. The first-line therapy for ALK-rearranged advanced NSCLC is tyrosine kinase inhibitors (TKI) targeting ALK. Following the development of crizotinib, the first ALK-TKI, patient prognosis has been greatly improved. Currently, five TKIs are approved by the FDA. In addition, clinical trials of the novel TKI, ensartinib, and fourth-generation ALK-TKI for compound ALK mutation are ongoing. Treatment with angiogenesis inhibitors and immune checkpoint inhibitors is also being studied. However, as the disease progresses, cancers tend to develop resistance mechanisms. In addition to ALK mutations, other mechanisms, including the activation of bypass signaling pathways and histological transformation, cause resistance, and the identification of these mechanisms is important in selecting subsequent therapy. Studies on tissue and liquid biopsy have been reported and are expected to be useful tools for identifying resistance mechanisms. The purpose of this manuscript is to provide information on the recent clinical trials of ALK-TKIs, angiogenesis inhibitors, immune checkpoint inhibitors, and chemotherapy to describe tissue and liquid biopsy as a method to investigate the mechanisms of resistance against ALK-TKIs and suggest a proposed treatment algorithm.

Keywords: non-small-cell lung cancer (NSCLC); anaplastic lymphoma kinase (ALK); tyrosine kinase inhibitors (TKI); angiogenesis inhibitors; immune checkpoint inhibitor (IO); resistance mechanism; biopsy

\section{Introduction}

Anaplastic lymphoma kinase (ALK) was first discovered as a fusion partner in the $(2 ; 5)$ chromosomal translocation in anaplastic large cell lymphoma in 1994 by Morris et al. [1]. ALK is a transmembrane tyrosine kinase encoded by the ALK gene localized on chromosome 2, belonging to the superfamily of insulin receptors. ALK expression is considered to be involved in the development of the nervous system [2]. ALK regulates several pathways involved in cell survival, proliferation, and cell cycling, including the AKT/PI3K [3] and STAT3 pathways $[4,5]$. The echinoderm microtubule-associated protein-like-4 (EML4)-ALK 
fusion gene was discovered in non-small cell lung cancer (NSCLC) in 2007 [6]. The EML-ALK fusion gene results from the fusion of the EML-4 gene and the ALK gene by inversion within chromosome $2 p$. The EML4-ALK fusion protein, produced from the EML4-ALK fusion gene, promotes carcinogenesis by activating an intrinsic tyrosine kinase. The anti-tumor effect of ALK-TKIs results from binding to the ATP-binding site of the intracellular tyrosine kinase domain, regulating signal transduction. Driver mutation is identified in 70-80\% of NSCLC [7]. ALK-rearrangement is associated with approximately $3-8 \%$ of NSCLC $[8,9]$. The patients reported to be likely to harbor ALK-rearrangement are young, never/light smokers with adenocarcinoma and have a higher risk of metastasis to the central nervous system [10,11]. In recent years, treatment for ALK-rearranged NSCLC has made remarkable progress. Nowadays, ALK lung cancer can be expected to survive 5 years. Currently, five ALK-TKIs are approved by the FDA. Since the FDA approval of crizotinib in 2011, ceritinib was approved in 2014, alectinib in 2015, brigatinib in 2017, and lorlatinib in 2018 (Figure 1). Furthermore, clinical trials of the novel ALK-TKIs, including ensartinib and fourth-generation ALK-TKI for compound ALK mutation, are ongoing. In addition, clinical trials of angiogenesis inhibitors, immune checkpoint inhibitors, and combination therapy of platinum doublet chemotherapy and ALK-TKI are ongoing. In this review, we provide information on the recent clinical trials on ALK-TKIs, angiogenesis inhibitors, immune checkpoint inhibitors, and chemotherapy, describe tissue and liquid biopsy as a method to investigate the mechanisms of resistance against ALK-TKIs, and suggest a proposed treatment algorithm.

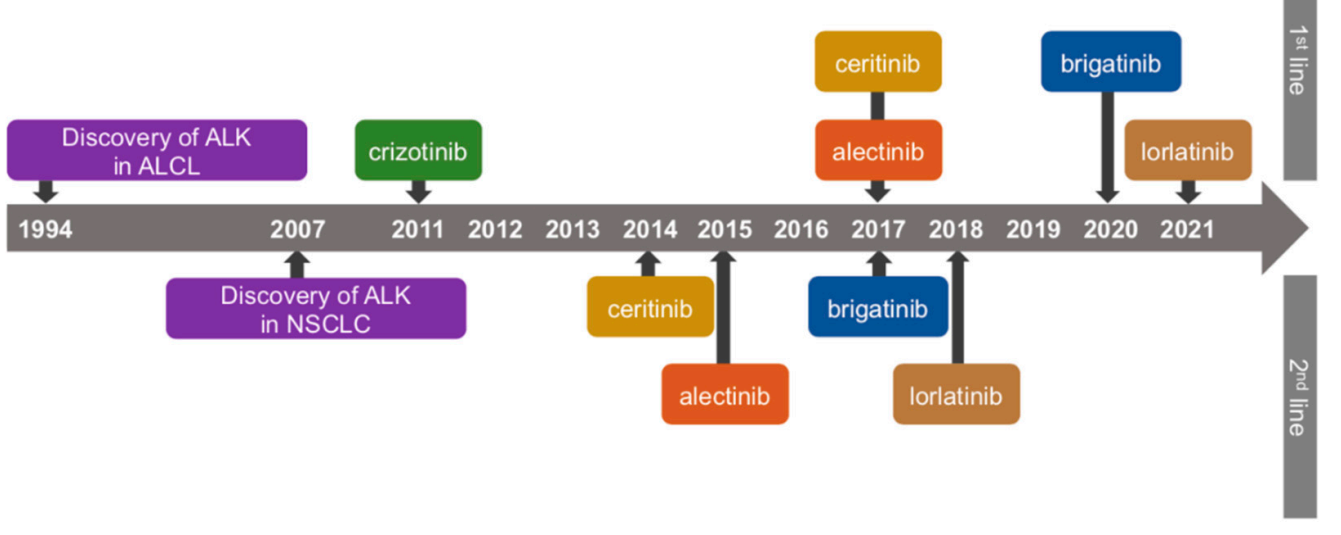

Figure 1. Timeline of discovery of ALK and US FDA approval of ALK-TKIs. ALCL: anaplastic large cell lymphoma, NSCLC: non-small cell lung cancer.

\section{Diagnosis}

International guidelines recommend testing for ALK mutations in all non-squamous NSCLC $[12,13]$. There are several methods to detect ALK-rearrangement: fluorescence in situ hybridization (FISH), immunohistochemistry (IHC), and polymerase chain reaction (PCR)-based next-generation sequencing (NGS). The choice of which test to use, and the algorithm is controversial and is an issue for consideration. The advantage of NGS is that it can be used in liquid biopsy using circulating tumor cells (ctDNA), etc., not only tissue samples, and it can detect drug resistance mechanisms. Identification of the resistance mechanism to ALK-TKIs and corresponding treatment are expected to improve prognoses. Liquid biopsy is aimed at predicting drug resistance mechanisms and treatment efficacy using specimens such as ctDNA, cell-free DNA (cfDNA), and circulating tumor DNA in the blood. The validity of ALK-rearrangement detection by liquid biopsy using NGS was demonstrated in the Blood First Assay Screening Trial (BFAST) [14] and the NILE (Noninvasive versus Invasive Lung Evaluation) study [15]. In the BFAST study, alectinib was shown to have a non-inferior outcome in patients with ALK-rearranged NSCLC diagnosed by blood-based NGS compared to those diagnosed by tissue-based NGS. The 
NILE study showed that cfDNA analysis using Guardant360 was non-inferior to tissue samples in detecting guideline-recommended biomarkers. These results demonstrated that for patients who, for some reason, do not have ALK-rearrangement identified in tissue samples, there is an opportunity to treat with ALK-TKIs based on blood-based NGS results. However, it has been reported that the level of detection of ALK-rearrangements by liquid biopsy is lower than that by tissue biopsy due to the small amount of acid released into the blood in small or slow-growing tumors, etc. [16]. Tissue biopsy and liquid biopsy have their own advantages and disadvantages. Tissue rebiopsy has advantages in histological evaluation, allowing for the evaluation of EMT transformation and gene amplification. Biopsies, however, are highly invasive and expensive because of the need for bronchoscopy or surgery. Liquid biopsy is not capable of histological evaluation but is non-invasive and is therefore repeatable and cost-effective. A liquid biopsy may be particularly useful when tissue samples are insufficient or when tissue biopsy is contraindicated. Detecting driver mutations and ALK resistance mutations as therapeutic targets is very beneficial, even when sufficient tissue samples are not available for biopsy. In addition, liquid biopsy is easily repeatable, allowing for real-time, long-term monitoring during treatment and the early detection of recurrence before clinical symptoms appear [17]. Although liquid biopsy for ALK-rearranged NSCLC is still under investigation, it is expected to be a useful tool for detecting genetic mutations with false-negative results by tissue biopsy and investigating resistance mechanisms.

\section{ALK-TKIs}

\subsection{Crizotinib}

Crizotinib is a multi-kinase inhibitor of tyrosine kinases, such as ALK, c-MET, and ROS-1. Crizotinib was the first ALK-TKI approved for the treatment of ALK-rearranged NSCLC. In part 2 of the phase I PROFILE 1001 trial for ROS1-rearranged NSCLC patients, two patients with ALK-rearrangements who received crizotinib $250 \mathrm{mg}$ orally twice daily showed a significant response. Therefore, the expanded cohort of patients with ALK-rearranged NSCLC stage III/IV was added in 2008 [18]. In this study, 143 patients with pre-treated or untreated ALK-rearranged NSCLC were included. Three patients had complete response (CR) and 84 patients had partial response (PR), with an overall response rate (ORR) of $60.8 \%$ (95\% CI: 52.3-68.9\%), median duration of response (DOR) of 49.1 weeks (95\% CI: 39.3-75.4\%), and median progression-free survival (mPFS) of 9.7 months (95\% CI: 7.7-12.8\%) [19]. The phase II PROFILE 1005 study included 1069 patients with previously treated ALK-rearranged advanced NSCLC [20]. In 908 patients determined to be ALKpositive at the central laboratory, the reported ORR was 54\% (95\% CI: 51-57), mPFS was 8.4 months (95\% CI: 7.1-9.7), and median overall survival (mOS) was 21.8 months (95\% CI: 9.4-24.0). Based on the results of phase I and II studies, in 2011, the FDA approved crizotinib as the first ALK-TKI for ALK-rearranged NSCLC. The phase III PROFILE 1007 study compared crizotinib with chemotherapy as second-line treatment in ALK-rearranged NSCLC patients whose disease had progressed after one prior platinum-based chemotherapy regimen [21]. The primary endpoint, mPFS, was 7.7 months (95\% CI: 6.0-8.8) in the crizotinib arm $(n=173)$ and 3.0 months (95\% CI: 2.6-4.3) in the chemotherapy arm (pemetrexed: 101, docetaxel: 73). ORR was 65\% (95\% CI: 58-72) with crizotinib compared to $20 \%$ (95\% CI: 14-26) with chemotherapy ( $p<0.001)$. Median DOR was 32.1 weeks (95\% CI: $2.1-72.4)$ in the crizotinib arm and 24.4 weeks (95\% CI: 3.0-43.6) in the chemotherapy arm (HR: 0.49, 95\% CI: 0.37-0.64). Based on the results of the PROFILE 1007 study, crizotinib was approved in 2013 for the second-line treatment of patients with ALK-rearranged NSCLC whose disease has progressed after platinum-based chemotherapy. In 2014, the phase III PROFILE 1014 study was conducted to evaluate the efficacy of crizotinib compared to pemetrexed plus platinum doublet chemotherapy as a first-line treatment for patients with ALK-rearranged advanced NSCLC [22,23]. In the PROFILE1014 study, the primary endpoint, mPFS, was 10.9 months (95\% CI: 8.3-13.9) in the crizotinib arm $(n=172)$ and 7.0 months $(95 \% \mathrm{CI}: 6.8-8.2)$ in the chemotherapy arm $(n=171)$ (HR: 0.45 (95\% CI: $0.35-0.60))$. ORR was 74\% (95\% CI: $67-$ 
$81)$ in the crizotinib arm and 45\% (95\% CI: 37-53) in the chemotherapy arm $(p<0.001)$. The median DOR was 11.3 months (95\% CI: 8.1-13.8) and 5.3 months (95\% CI: 4.1-5.8), respectively. Based on the result, crizotinib was approved as a first-line treatment for ALK-rearranged advanced NSCLC. In the recent analysis of the PROFILE 1014 study, mOS was not reached (NR) (95\% CI: 45.8-NR) in the crizotinib arm and 47.5 months (95\% CI: 32.2-NR) in the chemotherapy arm with HR of 0.76 (95\% CI: 0.548-1.053, $p=0.0978$ ), which was not statistically significant. Despite the prolonged PFS, crizotinib did not significantly improve OS, which may be due to the fact that $84.2 \%$ of patients in the chemotherapy arm crossed over to crizotinib and more effective treatments, such as other ALT-TKIs or chemotherapy, as subsequent therapy may have affected the results.

\subsubsection{Intracranial Efficacy}

It has been reported that crizotinib has low penetration of the blood-brain barrier (BBB) $[24,25]$. Lower cerebrospinal fluid (CSF) concentrations and CSF/plasma ratios prevent the achievement of therapeutic concentrations in the brain and lead to pharmacological tolerance. In the PROFILE 1014 study, the incidence of extracranial PD only was less with crizotinib than with chemotherapy, regardless of the presence or absence of brain metastasis (BM) prior to treatment initiation (ITT population: $73 \%$ vs. $80 \%$, BM present: $57 \%$ vs. $60 \%$, BM absent: $78 \%$ vs. $86 \%$ ). In contrast, the proportion of patients for whom the brain was the only site of PD was higher with crizotinib than with chemotherapy (ITT population: $24 \%$ vs. $10 \%$, BM present: $38 \%$ vs. $23 \%$, BM absent: $19 \%$ vs. $6 \%$ ). In contrast to crizotinib, the next-generation ALK-TKIs passed through the BBB and had higher concentrations in the CSF. The clinical trial comparing crizotinib with the next-generation ALK-TKIs showed that crizotinib had inferior activity in the CNS.

\subsubsection{Safety}

The characteristic adverse events of crizotinib are visual disturbances (diplopia, photophobia, and blurred vision). A total of $73 \%$ of patients in the PROFILE 1014 study had visual disturbances. The other frequent adverse events were gastrointestinal disorders: diarrhea occurred in $66 \%$ and nausea in $59 \%$ of patients. The most frequent grade $3-4$ adverse events were neutropenia $(15 \%)$, elevated transaminases $(14 \%)$, and pulmonary embolism ( $8 \%)$. In the PROFILE 1014 study, there was no significant difference in severe (RR: 0.97, 95\% CI: 0.79-1.18) and fatal (RR: 2.24,95\% CI: 0.49-10.30) adverse events between crizotinib and chemotherapy.

Recently, crizotinib has been used less frequently due to its inferior intracranial efficacy and shorter mPFS compared to next-generation ALK-TKIs.

\subsection{Ceritinib}

Ceritinib was approved by the FDA in 2014 based on the results of ASCEND-1 [26] and ASCEND-2 [27] for the treatment of NSCLC patients with ALK-rearrangement NSCLC who have progressed during treatment with crizotinib or who cannot tolerate crizotinib. In the phase I ASCEND-1 trial, 255 ALK-rearranged advanced NSCLC patients were treated with $750 \mathrm{mg} /$ day of ceritinib. In the ALK-TKI naive cohort $(n=83)$, ORR was 72.3\% $(95 \%$ CI: $61.4-81.6)$ with a median DOR of 17.0 months (11.3 not estimated (NE)), and in the ALK-TKI pretreated patient population $(n=163)$, ORR was $56.4 \%$ (95\% CI: 48.5-64.2), with a median DOR of 8.3 months (6.8-9.7). In the ALK-TKI naive cohort, mPFS was 18.4 months (11.1-NE), and in the patients who had previously received crizotinib, mPFS was 6.9 months (5.6-8.7). The phase II ASCEND-2 study evaluated the efficacy of $750 \mathrm{mg} /$ day of ceritinib in 140 patients who had received two or more prior treatment regimens, including crizotinib. ORR was reported to be $38.6 \%$ (95\% CI: 30.5-47.2\%), median DOR was 9.7 months (95\% CI: 7.1-11.1 months), and mPFS was 5.7 months (95\% CI: 5.4-7.6 months). In the phase III ASCEND-4 study comparing $750 \mathrm{mg}$ /day of ceritinib $(n=189)$ with platinum-based chemotherapy $(n=187)$ as first-line treatment, the primary endpoint, mPFS, was reported to be 16.6 months (95\% CI: 12.6-27.2) in the ceritinib arm and 8.1 months (95\% CI: 5.8-11.1) 
in the chemotherapy arm (HR: $0.55,95 \%$ CI: 0.42-0.73) [28]. Median OS was reported to be NR (95\% CI: 29.3-NE) in the ceritinib arm and 26.2 months (95\% CI: 22.8-NE) in the chemotherapy arm (HR: 0.73 (95\% CI: $0.50-1.08), p=0.056$ ). ORR was reported to be $72.5 \%$ (95\% CI: 65.5-78.7) in the ceritinib arm and 26.7\% (95\% CI: 20.5-33.7) in the chemotherapy arm. Based on the results of the ASCEND-4 study, the FDA approved ceritinib as a first-line treatment for ALK-rearranged advanced NSCLC in 2017. The ASCEND-5 study compared $750 \mathrm{mg} /$ day of ceritinib $(n=115)$ with chemotherapy $(n=116)$ (pemetrexed or docetaxel) in patients previously treated with chemotherapy and crizotinib. The primary endpoint, mPFS, was 5.4 months (95\% CI: 4.1-6.9) vs. 1.6 months (95\% CI: 1.4-2.8) in the ceritinib arm and the chemotherapy arm, respectively (HR: 0.49 (95\% CI: 0.36-0.67)). ORR was $39.1 \%$ (95\% CI: 30.2-48.7) in the ceritinib arm and 6.9\% (95\% CI: 3.0-13.1]) in the chemotherapy arm. Median OS was 18.1 months (95\% CI: 13.4-23.9) in the ceritinib arm and 20.1 months (95\% CI: 11.9-25.1) in the chemotherapy arm (HR: 1.0 (95\% CI: 0.67-1.49), $p=0.50$ ). In the phase II ASCEND-9 study, patients receiving ceritinib $750 \mathrm{mg} /$ day with prior treatment with alectinib $(n=20)$ had an ORR of $25 \%(95 \%$ CI: 8.7-49.1) and mPFS of 3.7 months (95\% CI: 1.9-5.3) [29]. Although there are no randomized clinical trials directly comparing ceritinib and crizotinib, an indirect analysis reported ceritinib prolongs mPFS (25.2 months vs. 10.8 months) (HR: 0.64 (95\% CI: 0.47-0.87)). However, OS did not differ significantly, with HR of 0.82 (95\% CI: 0.54-1.27) for ceritinib compared to crizotinib [30].

\subsubsection{Intracranial Efficacy}

In the ASCEND-4 study, intracranial ORR in patients with measurable brain metastases at baseline was $72.7 \%$ (CR: 2, PR: 14$)$ in the ceritinib arm $(n=22)$ and $27.3 \%$ (CR: 2, PR: $4)$ in the chemotherapy arm $(n=22)$. The median intracranial duration of intracranial response (IC-DOR) was 16.6 months (95\% CI: 8.1-NE) in the ceritinib arm. The median IC-DOR could not be estimated in the chemotherapy arm because four of six patients had not progressed at analysis.

\subsubsection{Safety}

The characteristic adverse events of ceritinib are gastrointestinal and hepatic disorders. In the ASCEND4 study (750 mg/day of ceritinib), diarrhea occurred in 85\% (grades 3-4: $5 \%$ ), nausea in $69 \%$ (grades 3-4: $3 \%$ ), vomiting in $66 \%$ (grades 3-4: $5 \%$ ), and increased ALT in 60\% (grades 3-4: 31\%). In the phase I ASCEND-8 study, a total of 306 patients were included and randomized to receive $450 \mathrm{mg}$ with food $(n=108), 600 \mathrm{mg}$ with food $(n=87)$, or $750 \mathrm{mg}$ fasted $(n=111)$ of ceritinib. Of these, 304 patients were included in the safety analysis, and 198 untreated patients were included in the efficacy analysis. ORR was 78.1\% (95\% CI: 66.9-86.9), 72.5\% (95\% CI: 58.3-84.1), and 75.7\% (95\% CI: 64.3-84.9) for each dose groups. Median DOR was NE (95\% CI: 11.2-NE), 20.7 (95\% CI: 15.8-NE), and 15.4 (95\% CI: 8.3-NE), respectively. In the safety analysis, the $450 \mathrm{mg}$ dose group reported the lowest percentage of patients who had dose reductions (24.1\%:65.1\%:60.9\%) and the lowest percentage of patients who exhibited gastrointestinal toxicity $(75.9 \%: 82.6 \%: 91.8 \%)$. This result suggests that ceritinib $450 \mathrm{mg}$ with food was shown to be non-inferior in efficacy to ceritinib $750 \mathrm{mg}$ in fasted and better tolerated for gastrointestinal adverse effects [31]. In fact, in the ceritinib $750 \mathrm{mg}$ /day group, diarrhea occurred in $64.4 \%$, nausea in $62.2 \%$, vomiting in $42.2 \%$, and abdominal pain in $31.1 \%$, while in the ceritinib $450 \mathrm{mg} /$ day group, diarrhea occurred in $47.7 \%$, nausea in $45.5 \%$, vomiting in $22.7 \%$, and abdominal pain in $22.7 \%$.

Despite these efforts to counteract adverse events, ceritinib is still used less often than other ALK-TKIs due to gastrointestinal toxicity issues and the fact that crizotinib is not the control arm in the ASCEND-4 study, which led to its approval for first-line therapy.

\subsection{Alectinib}

Alectinib is a second-generation ALK-TKI and is currently one of the most commonly used first-line therapies. The initial phase III study was the J-ALEX study conducted in 
Japan [32,33]. A total of 207 Japanese patients in the J-ALEX study received either alectinib $300 \mathrm{mg}$ twice daily $(n=103)$ or crizotinib $250 \mathrm{mg}$ twice daily $(n=104)$ as first-line treatment. Median PFS, the primary endpoint, was 34.1 months (95\% CI: 22.1-NE) in the alectinib arm and 10.2 months (95\% CI: 8.3-12.0) in the crizotinib arm (HR: 0.37 (95\% CI: 0.26-0.52)). In the final report of J-ALEX, there was no prolongation of mOS in the alectinib arm compared with the crizotinib arm (NR vs. 43.7 months, HR: 0.80 (95\% CI: 0.35-1.82), $p=0.3860$ ). The phase III ALEX trial, conducted with 303 treatment-naive, ALK-rearranged advanced NSCLC patients, compared alectinib at $600 \mathrm{mg}$ twice daily $(n=152)$ with crizotinib at $250 \mathrm{mg}$ twice daily $(n=151)$ in first-line treatment [34-37]. ORR was $82.9 \%(95 \%$ CI: 75.95-88.51) in the alectinib arm and 75.5\% (95\% CI: 67.84-82.12) in the crizotinib arm. In a recent report, the primary endpoint of mPFS was 34.8 months (95\% CI: 17.7-NE) in the alectinib arm and 10.9 months (95\% CI: 9.1-12.9) in the crizotinib arm (HR: 0.43 (95\% CI: 0.32-0.58)). Immature OS data showed that mOS was NR with alectinib versus 57.4 months with crizotinib (HR: 0.67 (95\% CI: 0.46-0.98)), indicating a statistically significant OS benefit of alectinib over crizotinib, despite $53.5 \%$ of patients receiving other ALK-TKIs by crossover after resistance to alectinib. The ALEX trial is still ongoing (NCT:02075840). In the phase III ALESIA, enrolling only Asian patients with ALK-rearranged advanced NSCLC, alectinib at $600 \mathrm{mg}$ twice daily $(n=125)$ was compared with crizotinib at $250 \mathrm{mg}$ twice daily $(n=62)$ as first-line treatment. The median PFS was NE vs. 11.1 months (HR: 0.22 (95\% CI: 0.13-0.38)). ORR was $91 \%$ vs. $77 \%$. DOR was longer in the alectinib arm than in the crizotinib arm (HR: 0.22 (95\% CI: $0.12-0.40), p<0.0001)$.

\subsubsection{Intracranial Efficacy}

In the ALEX trial, alectinib was reported to have a better intracranial response compared to crizotinib. The CNS ORR in patients with measurable CNS metastases at baseline was $85.7 \%$ in the alectinib arm versus $71.4 \%$ in the crizotinib arm in patients with previous radiotherapy and $78.6 \%$ in alectinib arm versus $40.0 \%$ in crizotinib arm in patients without previous radiotherapy. In patients with measurable/not measurable baseline CNS metastases, CNS DOR was NR (95\% CI: 14.8-NR) in the alectinib arm and 11.1 months (95\% CI: 13.7-18.1) in the crizotinib arm in patients with prior radiotherapy. The CNS DOR in patients without previous radiotherapy was NR (95\% CI: 13.4-NR) in the alectinib arm and 3.7 months (95\% CI: 2.3-5.5) in the crizotinib arm, which was longer than that for crizotinib.

\subsubsection{Safety}

The most common adverse events of all grades in the ALEX trial with a difference in frequency of $5 \%$ or more compared to crizotinib were anemia $(20 \%)$, peripheral edema $(17 \%)$, myalgia (16\%), increased ALT (15\%), increased AST (14\%), increased blood bilirubin $(15 \%)$, nausea $(14 \%)$, and diarrhea (12\%). The most common grade $3-5$ adverse events were anemia (5\%), increased ALT (5\%), and increased AST (5\%). In a recent report, both alectinib and crizotinib grade $3-5$ adverse events (52.0\% vs. $56.3 \%$ ), adverse events leading to dose reduction (20.4\% vs. $19.9 \%)$, adverse events requiring dose interruption ( $26.3 \%$ vs. $26.5 \%)$, and adverse events requiring treatment discontinuation (14.5\% vs. $14.6 \%)$ were similar in frequency.

\subsection{Lorlatinib}

Lorlatinib, a third-generation ALK-TKI, was developed to target mutations conferring resistance to crizotinib and next-generation TKIs, and as a selective, brain-penetrating ALK-TKI. Unlike first- and second-generation ALK-TKIs, which are acyclic ALK-TKIs, lorlatinib is a macrocyclic ALK-TKI, which is smaller and more compact, making it sensitive to ALK mutations resistant to first- and second-generation ALK-TKIs, such as G1202R. In the phase II study, the primary endpoints were ORR and intracranial tumor response [38]. Patients with ALK-rearranged NSCLC were enrolled in the following expansions. No prior treatment (EXP1: $n=30)$, prior crizotinib treatment without chemotherapy (EXP2: $n=27)$, prior crizotinib treatment with chemotherapy (EXP3A: $n=32$ ), prior non- 
crizotinib ALK-TKI with/without chemotherapy (EXP3B: $n=28$ ), prior two ALK-TKI treatments with/without chemotherapy (EXP4: $n=66)$ or prior three ALK-TKI treatments with/without chemotherapy (EXP5: $n=46)$. In EXP1, ORR was 90.0\% (95\% CI: 73.5-97.9) and mPFS was NR (95\% CI: 11.4-NR). In EXP2-5, ORR was 47.0\% (95\% CI: 39.9-54.2) and mPFS was 7.3 months (95\% CI: 5.6-11.0). In EXP2-3A, ORR was 69.5\% (95\% CI: 56.1-80.8) and mPFS was NR (95\% CI: 12.5-NR). In EXP3B, ORR was 32.1\% (95\% CI: 15.9-52.4) and mPFS was 5.5 months (95\% CI: 2.7-9.0). In EXP4-5, ORR was 38.7\% (95\% CI: 29.6-48.5) and mPFS was 6.9 months (95\% CI: 5.4-9.5). Based on the results of this trial, the FDA approved lorlatinib for patients with ALK-rearranged advanced NSCLC progressing on crizotinib and at least one other ALK-TKI, or after first-line treatment with non-crizotinib ALK-TKI, in November 2018. In the phase III CROWN trial, 296 untreated patients with ALK-rearranged advanced NSCLC were randomized to receive lorlatinib at $100 \mathrm{mg}$ once daily $(n=149)$ or crizotinib at $250 \mathrm{mg}$ twice daily $(n=147)$ [39]. The primary endpoint, mPFS, was NR vs. 9.3 months (95\% CI: 7.6-11.1) at a median follow-up of 18.3 months for lorlatinib and 14.8 months for crizotinib (HR: 0.28 (95\% CI: 0.191-0.413)). The proportion of patients who were alive without disease progression at 12 months was 78\% (95\% CI: 70-84) in the lorlatinib arm and 39\% (95\% CI: 30-48) in the crizotinib arm (HR: 0.28 (95\% CI: $0.19-0.41), p<0.001)$. ORR was 76\% (95\% CI: 68-83) for lorlatinib and 58\% (95\% CI: 49-66) for crizotinib. The HR for death was 0.72 (95\% CI: 0.41-1.25) in the immature OS analysis at the data-cutoff point, which was not significant. Based on the result of the CROWN trial, the FDA approved lorlatinib as a first-line treatment for patients with ALK-rearranged NSCLC in March 2021. The CROWN trial is still ongoing (NCT:03052608).

\subsubsection{Intracranial Efficacy}

Lorlatinib was developed for its potential effect on the CNS and has been reported to have excellent efficacy. Phase II results showed that intracranial ORR in EXP1 $(n=3)$ was $66.7 \%$ (95\% CI: 9.4-99.2), with a median DOR of NR, and intracranial ORR in EXP2-5 $(n=198)$ was $63 \%$ (95\% CI: 51.5-73.4), with a median DOR of 14.5 months (95\% CI: $8.4-14.5)$. In the CROWN trial, intracranial ORR was $66 \%(95 \% \mathrm{CI}: 49-80)$ in the lorlatinib arm $(n=38)$ and 20\% (95\% CI: 9-36) in the crizotinib arm $(n=40)$ among patients with measurable or non-measurable CNS metastases at baseline. Median DOR was NR in the lorlatinib arm and 9.4 months (95\% CI: 6.0-11.1) in the crizotinib arm. The proportion of patients with intracranial response lasting longer than 12 months was $72 \%$ in the lorlatinib arm and $0 \%$ in the crizotinib arm. Of patients with measurable CNS metastases at baseline, intracranial ORR was $82 \%(95 \%$ CI: 57-96) in the lorlatinib arm $(n=17), 23 \%(95 \%$ CI: $5-54)$ in the crizotinib arm $(n=13)$, and CR was $71 \%$ and $8 \%$, respectively. Median DOR was reported to be NE in the lorlatinib arm and 10.2 months (95\% CI: 9.4-11.1) in the crizotinib arm.

\subsubsection{Safety}

In the CROWN trial, adverse events that occurred more frequently $(\geq 10 \%)$ in the lorlatinib arm than in the crizotinib arm were hypercholesterolemia (70\%), hypertriglyceridemia (64\%), edema (55\%), weight gain (38\%), peripheral neuropathy $(34 \%)$, cognitive effects $(21 \%)$, and diarrhea $(21 \%)$. Hypercholesterolemia and hypertriglyceridemia can usually be easily managed with lipid-lowering drugs and dose modification. Cognitive effects and mood effects (16\%) were typically grade 1 and reversible with dose interruption. Grade 3-4 adverse events occurred in $72 \%$ of patients treated with lorlatinib. The most common grade 3-4 adverse events in the lorlatinib arm were elevated triglycerides (20\%), weight gain $(17 \%)$, elevated cholesterol (16\%), and hypertension (10\%). Adverse events that led to withdrawal occurred in $49 \%$ of patients, dose reduction in $21 \%$, and treatment discontinuation in $7 \%$.

Lorlatinib has been an ALK-TKI frequently used after first-line treatment but based on the results of the phase III CROWN trial, lorlatinib is expected to be used more frequently in first-line treatment. Whether it is better to use lorlatinib after second-generation ALK-TKI treatment or in the first-line setting requires further study. 


\subsection{Brigatinib}

In the phase II ALTA trial, the efficacy of brigatinib was evaluated in 222 patients with ALK-rearranged advanced NSCLC previously treated with crizotinib. Patients were randomized 1:1 to receive brigatinib $90 \mathrm{mg}$ once daily $(n=112)$ or brigatinib $180 \mathrm{mg}$ once daily with a 7-day lead-in at $90 \mathrm{mg}(n=110)$ [40]. The primary endpoint, ORR, was $46 \%$ (95\% CI: 35-57\%) and 56\% (95\% CI: 45-67\%), respectively. Median DOR was 12.0 months (95\% CI: 9.2-17.7) and 13.8 months (95\% CI: $10.2-19.3)$, and mPFS was 9.2 months (95\% CI: 7.4-12.8) and 16.7 months (95\% CI: 11.6-21.4), for each dose. Median OS was 29.5 months (95\% CI: 18.2-NR) and 34.1 months (95\% CI: 27.7-NR), respectively. Following the results of the ALTA trial, in April 2017, the FDA approved brigatinib for the treatment of patients with ALK-rearranged NSCLC who have progressed on or are intolerant to crizotinib. The phase III ALTA-1L trial compared brigatinib $(n=137)$ with crizotinib $(n=138)$ as a first-line treatment [41-43]. In the interim analysis, ORR was $74 \%$ (95\% CI: $66-81)$ vs. $62 \%$ (95\% CI: 53-70), and DOR was NR (95\% CI: 19.4-NR) vs. 13.8 months (95\% CI: 9.3-20.8), respectively. The primary endpoint, mPFS, was 24.0 months (95\% CI: 18.4-43.2) in the brigatinib arm and 11.1 months (95\% CI: 9.1-13.0) in the crizotinib arm (HR: 0.48 (95\% CI: $0.35-0.66)$ ). Immature OS data at final analysis indicated similar OS in the two groups (HR: 0.81 (95\% CI: 0.53-1.22), $p=0.305$ ). However, OS may be affected by imbalances in subsequent anticancer therapy, such as a higher rate of crossover to brigatinib and a higher rate of subsequent anticancer therapy after discontinuation of study treatment in the crizotinib arm. A sensitivity analysis of OS adjusted for possible confounding by crossover suggested that treatment with brigatinib was associated with improved OS in the absence of treatment crossover in the crizotinib arm $(\mathrm{HR}=0.54)$. Based on the results of the ALTA-1L trial, the FDA approved brigatinib as a first-line treatment for patients with ALK-rearranged advanced NSCLC in May 2020. The efficacy of brigatinib after second-generation ALKTKI therapy has been evaluated in subsequent trials. In the subgroup analysis of the international expanded access program (EAP), the median time to discontinuation of brigatinib was 8.72 months (95\% CI: 7.50-14.93) after treatment with alectinib $(n=111)$, 10.33 months (95\% CI: 8.13-13.93) after treatment with ceritinib $(n=249)$, and 7.5 months (95\% CI: 4.47-NE) after treatment with lorlatinib $(n=37)$ [44]. The phase II J-ALTA trial evaluated the efficacy and safety of brigatinib in 72 Japanese patients previously treated with ALK-TKIs, including alectinib. In 47 patients previously treated with alectinib, ORR was 34\% (95\% CI: 21-49), median DOR was 11.8 months (95\% CI: 5.5-16.4), and mPFS was 7.3 months (95\% CI: 3.7-9.3) [45]. The phase II ALTA-2 trial [46] (NCT:03535740) evaluating its efficacy as a subsequent treatment after treatment with alectinib or ceritinib and the phase III ALTA-3 trial [47] (NCT:03596866), comparing its efficacy with alectinib as a subsequent treatment after crizotinib are ongoing.

\subsubsection{Intracranial Efficacy}

The interim analysis of the phase III ALTA-1L trial showed that in patients with measurable brain metastases, intracranial ORR was $78 \%$ (14/18) (95\% CI: 52-94) for brigatinib and $26 \%(6 / 23)(95 \%$ CI: 10-48) for crizotinib. The final results showed that median intracranial DOR for patients with measurable brain metastases at baseline was 27.9 months (95\% CI: 5.7-NE) in the brigatinib arm and 9.2 months (95\% CI: 3.9-NE) in the crizotinib arm. In patients with brain metastases at baseline, the 3-year intracranial PFS rate was 31\% (95\% CI: 17-47) with brigatinib and 9\% (95\% CI: 2-25) with crizotinib (HR: $0.29,95 \%$ CI: $0.17-0.51$ ), and the 4-year rate was 22\% (95\% CI: 9-39\%) with brigatinib and NE with crizotinib.

\subsubsection{Safety}

Frequent adverse events reported in the ALTA-1L trial compared with crizotinib were diarrhea (52\%), increased blood creatine phosphokinase (46\%), cough (35\%), hypertension $(32 \%)$, nausea $(30 \%)$, increased AST $(26 \%)$, increased lipase $(23 \%)$, increased ALT $(21 \%)$, vomiting $(21 \%)$, and dyspnea $(21 \%)$. Common grade 3 or higher adverse events were increased blood creatine phosphokinase (24\%), increased lipase (14\%), and hyperten- 
sion $(12 \%)$. In the final analysis, $13 \%$ of adverse events led to treatment discontinuation, $44 \%$ led to dose reduction, and $72 \%$ led to dose interruption. Interstitial lung disease (ILD)/pneumonia is a characteristic adverse event of brigatinib. In the ALTA-1L trial, ILD/pneumonia occurred in 5\% of patients (grade 3-4 ILD/pneumonia in 3\%/1\%), and ILD/pneumonia was reported to occur earlier after initiation of treatment in the ALTA study (median: day 2; range: days 1-9).

\subsection{Ensartinib}

In the phase I/II trial, the efficacy and safety of ensartinib were evaluated [48]. In dose escalation, patients with advanced solid tumors were administered ensartinib at doses of 25 to $250 \mathrm{mg}$ once daily, and in dose expansion, patients with advanced ALK-rearranged NSCLC were administered additional doses of $225 \mathrm{mg}$ once daily. ORR was $60 \%$ (95\% CI: 47.4-71.4) and mPFS was 9.2 months (95\% CI: 5.6-11.7) in 60 patients with ALK-rearranged NSCLC. In ALK-TKI-naive patients, ORR was $80 \%$, and mPFS was 26.2 months (95\% CI: 9.2-NE). In patients previously treated with crizotinib alone, ORR was $69 \%$, and mPFS was 9.0 months (95\% CI: 5.6-11.7). In the group previously treated with crizotinib and a second-generation ALK-TKI, mPFS was 1.9 months (95\% CI: 1.7-5.7). The phase III eXalt3 study compared $225 \mathrm{mg}$ of ensartinib once daily $(n=143)$ with $250 \mathrm{mg}$ of crizotinib twice daily $(n=147)$ in 290 patients with ALK-rearranged untreated advanced NSCLC [49]. The primary endpoint, mPFS, was 25.8 months (95\% CI: 0.03-44.0) in the ensartinib arm and 12.7 months (95\% CI: 0.03-38.6) in the crizotinib arm (HR: 0.51 (95\% CI: 0.36-0.72)). Median DOR was NR (95\% CI: 22.0-NR) in the ensartinib arm and 27.3 months (95\% CI: 12.9-NR) in the crizotinib arm. The eXalt3 study is currently ongoing (NCT:02767804). Ensartinib is expected to be approved by the FDA to treat ALK-rearranged advanced NSCLC based on the eXalt3 study.

\subsubsection{Intracranial Efficacy}

In the phase I/II trial, 14 patients had CNS-targeted lesions at baseline. ORR of $64.3 \%$ (95\% CI: 38.8-83.7) was reported with two patients with CR and seven patients with PR. In the eXalt3 study, intracranial ORR in patients with measurable brain metastases was $54 \%$ for ensartinib and $19 \%$ for crizotinib. In patients with intracranial disease, ORR was $64 \%$ for ensartinib and $21 \%$ for crizotinib, delaying the incidence of new central lesions in patients without baseline brain metastases (23.9 months vs. 4.2 months, HR: 0.32 (95\% CI: $0.15-0.64)$ ).

\subsubsection{Safety}

In the interim analysis of the phase III eXalt3 study, rash (67.8\%), increased AST $(37.8 \%)$, increased ALT (48.3\%), pruritus (26.6\%), nausea $(22.4 \%)$, constipation $(20.3 \%)$, edema $(21.0 \%)$, anemia $(14.0 \%)$, vomiting $(11.9 \%)$, increased ALP $(13.3 \%)$, increased blood creatinine $(14.0 \%)$, increased $\gamma$-GTP $(13.3 \%)$, and anorexia $(11.2 \%)$ were reported. Grade 3 rash was reported in $11.2 \%$ of patients, requiring dose interruption or reduction. Dose reduction in $24 \%$ of patients and discontinuation of treatment in $9 \%$ were required due to adverse events, such as rash and liver toxicity.

The summary of six TKIs is in the tables below (Tables 1-4). 
Table 1. Clinical trials as first-line treatment.

\begin{tabular}{|c|c|c|c|c|c|c|c|c|c|c|c|}
\hline Clinical Trial & ALK-TKI & Control Arm & Patients (n) & ORR (\%) & $\begin{array}{c}\text { mPFS } \\
\text { (Months) }\end{array}$ & $\begin{array}{l}\text { PFS HR } \\
(95 \% \mathrm{CI})\end{array}$ & $\begin{array}{c}\text { Median } \\
\text { Follow-Up } \\
\text { Duration for PFS }\end{array}$ & $\begin{array}{c}\text { mOS } \\
\text { (Months) }\end{array}$ & $\begin{array}{c}\text { OS HR } \\
(95 \% \text { CI) }\end{array}$ & $\begin{array}{c}\text { Median } \\
\text { Follow-Up } \\
\text { Duration for OS }\end{array}$ & Ref \\
\hline PROFILE1014 & Crizotinib & $\begin{array}{l}\text { platinum } \\
\text { doublet }\end{array}$ & $172 / 171$ & 74 vs. 45 & 10.9 vs. 7.0 & $\begin{array}{c}0.45 \\
(0.35-0.60)\end{array}$ & NA & NR vs. 47.5 & $\begin{array}{c}0.76 \\
(0.55-1.05)\end{array}$ & 45.7 months & {$[22,23]$} \\
\hline ASCEND-4 & Ceritinib & $\begin{array}{l}\text { platinum } \\
\text { doublet }\end{array}$ & $189 / 187$ & 72.5 vs. 50 & 16.6 vs. 8.1 & $\begin{array}{c}0.55 \\
(0.42-0.73)\end{array}$ & 12.4 months & NR vs. 26.2 & $\begin{array}{c}0.73 \\
(0.50-1.08)\end{array}$ & NA & [28] \\
\hline ALEX & Alectinib & Crizotinib & $152 / 151$ & 82.9 vs. 75.5 & 34.8 vs. 10.9 & $\begin{array}{c}0.43 \\
(0.32-0.58)\end{array}$ & 37.8 months & NR vs. 57.4 & $\begin{array}{c}0.67 \\
(0.46-0.98)\end{array}$ & 48.2 months & [34-37] \\
\hline J-ALEX & Alectinib & Crizotinib & $103 / 104$ & 92 vs. 79 & 34.1 vs. 10.2 & $\begin{array}{c}0.37 \\
(0.26-0.52)\end{array}$ & 42.4 months & NR vs. 43.7 & $\begin{array}{c}0.80 \\
(0.35-1.82)\end{array}$ & NA & {$[32,33]$} \\
\hline CROWN & Lorlatinib & Crizotinib & $149 / 147$ & 76 vs. 58 & NR vs. 9.3 & $\begin{array}{c}0.28 \\
(0.19-0.41)\end{array}$ & 18.3 months & NR & $\begin{array}{c}0.72 \\
(0.41-1.25)\end{array}$ & NA & [39] \\
\hline ALTA-1L & Brigatinib & Crizotinib & $137 / 138$ & 74 vs. 62 & 24.0 vs. 11.1 & $\begin{array}{c}0.48 \\
(0.35-0.66)\end{array}$ & 40.4 months & NR & $\begin{array}{c}0.81 \\
(0.53-1.22)\end{array}$ & NA & [41-43] \\
\hline eXalt3 & Ensartinib & Crizotinib & $143 / 147$ & 74 vs. 67 & 25.8 vs. 12.7 & $\begin{array}{c}0.51 \\
(0.36-0.72)\end{array}$ & 23.8 months & NR & NA & NA & [49] \\
\hline
\end{tabular}

ORR: overall response rate, mPFS: median progression-free survival, median overall survival.

Table 2. Efficacy following second-generation TKI treatment.

\begin{tabular}{|c|c|c|c|c|c|c|c|}
\hline Clinical Trial & ALK-TKI & Treatment Line & Prior Treatment & Patients (n) & ORR $(95 \% \mathrm{CI})$ & $\begin{array}{l}\text { mPFS (Months) } \\
(95 \% \mathrm{CI})\end{array}$ & Ref \\
\hline ASCEND-9 & Ceritinib & $\geq 2$ & $\begin{array}{l}\text { Alectinib (+Chemo } \\
\text { or Crizotinib) }\end{array}$ & 20 & $25 \%(8.7-49.1)$ & $3.7(1.9-5.3)$ & [29] \\
\hline \multirow{2}{*}{ Phase II study } & \multirow{2}{*}{ Lorlatinib } & \multirow{2}{*}{$\geq 2$} & EXP3B * & 28 & $32.1 \%(15.9-52.4)$ & $5.5(2.7-9.0)$ & \multirow{2}{*}{ [38] } \\
\hline & & & EXP4-5* & 111 & $38.7 \%(29.6-48.5)$ & $6.9(5.4-9.5)$ & \\
\hline \multirow{4}{*}{$\begin{array}{l}\text { the } \\
\text { international EAP }\end{array}$} & \multirow{4}{*}{ Brigatinib } & \multirow{4}{*}{$\geq 2$} & at least one ALK inhibitor & & & $\begin{array}{l}\text { Time to treatment } \\
\text { discontinuation }\end{array}$ & \\
\hline & & & Alectinib & 111 & NA & $8.72(7.50-14.93)$ & \multirow{3}{*}{ [44] } \\
\hline & & & Ceritinib & 249 & NA & $10.33(8.13-13.62)$ & \\
\hline & & & Lorlatinib & 37 & NA & 7.5 (4.47-NE) & \\
\hline
\end{tabular}

* EXP3B: Previous non-crizotinib ALK-TKI with or without chemotherapy, ${ }^{*}$ EXP4-5: $\geq 2$ previous ALK-TKIs with or without chemotherapy.

Table 3. Efficacy for measurable brain metastases in first-line treatment.

\begin{tabular}{|c|c|c|c|c|c|c|c|}
\hline Clinical Trial & ALK-TKI & & Control Arm & Patients (n) & IC-ORR (\%) & $\begin{array}{l}\text { Median IC-DOR (Months) }(95 \% \\
\text { CI) }\end{array}$ & Ref \\
\hline \multirow{2}{*}{ ALEX } & \multirow{2}{*}{ Alectinib } & $\mathrm{RT}+$ & Crizotinib & $7 / 7$ & 85.7 vs. 71.4 & NR (14.8-NR) vs. 11.1 (13.7-18.1) & \multirow{2}{*}{ [37] } \\
\hline & & RT - & Crizotinib & $14 / 15$ & 78.6 vs. 40.0 & NR (13.4-NR) vs. 3.7 (2.3-5.5) & \\
\hline ASCEND-4 & Ceritinib & & platinum doublet & $22 / 22$ & 72.7 vs. 27.3 & 16.6 (8.1-NE) vs. NE & [28] \\
\hline CROWN & Lorlatinib & & Crizotinib & $17 / 13$ & 82 vs. 23 & NE vs. $10.2(9.4-11.1)$ & [39] \\
\hline ALTA & Brigatinib & & Crizotinib & $18 / 23$ & 78 vs. 26 & 27.9 (5.7-NE) vs. 9.2 (3.9-NE) & [40] \\
\hline eXalt3 & Ensartinib & & Crizotinib & $13 / 21$ & 54 vs. 19 & NA & [49] \\
\hline
\end{tabular}

RT: radiation therapy, IC-ORR: intracranial overall response rate, IC-DOR: intracranial duration of response. 
Table 4. Characteristics of molecule and common/typical adverse effects.

\begin{tabular}{|c|c|c|c|c|c|c|c|c|c|c|c|c|c|c|c|c|c|c|}
\hline ALK-TKI & \multicolumn{3}{|c|}{ Crizotinib } & \multicolumn{3}{|c|}{ Ceritinib } & \multicolumn{3}{|c|}{ Alectinib } & \multicolumn{3}{|c|}{ Lorlatinib } & \multicolumn{3}{|c|}{ Brigatinib } & \multicolumn{3}{|c|}{ Ensartinib } \\
\hline $\begin{array}{c}\text { Molecular } \\
\text { formula }\end{array}$ & \multicolumn{3}{|c|}{$\mathrm{C} 21 \mathrm{H} 22 \mathrm{Cl} 2 \mathrm{FN} 5 \mathrm{O}$} & \multicolumn{3}{|c|}{$\mathrm{C} 28 \mathrm{H} 36 \mathrm{ClN} 5 \mathrm{O} 3 \mathrm{~S}$} & \multicolumn{3}{|c|}{$\mathrm{C} 30 \mathrm{H} 34 \mathrm{~N} 4 \mathrm{O} 2 \mathrm{HCl}$} & \multicolumn{3}{|c|}{$\mathrm{C} 21 \mathrm{H} 19 \mathrm{FN} 6 \mathrm{O} 2$} & \multicolumn{3}{|c|}{ C29H39CIN7O2P } & \multicolumn{3}{|c|}{$\mathrm{C} 26 \mathrm{H} 27 \mathrm{C} 12 \mathrm{FN} 6 \mathrm{O} 3$} \\
\hline $\begin{array}{l}\text { Characteristics } \\
\text { of molecule }\end{array}$ & \multicolumn{3}{|c|}{ acyclic } & \multicolumn{3}{|c|}{ acyclic } & \multicolumn{3}{|c|}{ acyclic } & \multicolumn{3}{|c|}{ macrocyclic } & \multicolumn{3}{|c|}{ acyclic } & \multicolumn{3}{|c|}{$\mathrm{NA}$} \\
\hline Dosage & \multicolumn{3}{|c|}{$250 \mathrm{mg}$ twice/day } & \multicolumn{3}{|c|}{$450 \mathrm{mg}$ once/day(fed) } & \multicolumn{3}{|c|}{$600 \mathrm{mg}$ twice/day } & \multicolumn{3}{|c|}{$100 \mathrm{mg}$ once/day } & \multicolumn{3}{|c|}{$180 \mathrm{mg}$ once/day $(7$ day lead-in at $90 \mathrm{mg} /$ day $)$} & \multicolumn{3}{|c|}{$225 \mathrm{mg}$ once/day } \\
\hline AEs $(\%)$ & & any grade & grade $\geqq 3$ & & any grade & grade $\geqq 3$ & & any grade & grade $\geqq 3$ & & any grade & grade $\geqq 3$ & & any grade & grade $\geqq 3$ & & any grade & grade $\geqq 3$ \\
\hline & $\begin{array}{c}\text { Vision } \\
\text { disorder }\end{array}$ & 73.1 & 0.6 & Diarrhea & 57.4 & 0.9 & Conspitation & 36.8 & 0.0 & Hypercholesterolemia & 70 & 16 & Diarrhea & 58 & 2 & Rash & 59.4 & 11.2 \\
\hline & Diarrhea & 65.5 & 2.9 & Vomiting & 38.9 & 1.9 & Anemia & 26.3 & 5.9 & Hypertriglyceridemia & 64 & 20 & Elevated CPK & 50 & 26 & Elevated ALT & 46.2 & 4.2 \\
\hline & Nausea & 59.1 & 1.8 & Nausea & 41.7 & 0 & Fatigue & 22.4 & 0 & Edema & 55 & 4 & Nausea & 33 & 2 & Elevated AST & 37.1 & 0.7 \\
\hline & Vomiting & 50.9 & 2.3 & Elevated ALT & 35.2 & 7.4 & $\begin{array}{c}\text { Peripheral } \\
\text { edema }\end{array}$ & 19.1 & 0 & $\begin{array}{l}\text { Peripheral } \\
\text { neuropathy }\end{array}$ & 34 & 2 & Elevated AST & 26 & 4 & Cough & 30.1 & 0.7 \\
\hline & Constipation & 45.6 & 1.8 & $\begin{array}{c}\text { Elevated } \\
\gamma-G T P\end{array}$ & 33.3 & 22.2 & Elevated ALT & 17.8 & 4.6 & Cognitive effects & 21 & 2 & Back pain & 26 & 0 & Prurtius & 28.0 & 2.1 \\
\hline & $\begin{array}{c}\text { Upper } \\
\text { respiratory } \\
\text { infection }\end{array}$ & 39.8 & 0 & Fatigue & 22.2 & 0.9 & Elevated AST & 17.1 & 5.3 & Hypertension & 18 & 10 & Elevated lipase & 24 & 15 & Nausea & 26.6 & 1.4 \\
\hline & $\begin{array}{c}\text { Elevated } \\
\text { transaminases }\end{array}$ & 39.2 & 14 & $\begin{array}{c}\text { Abdominal } \\
\text { pain }\end{array}$ & 20.4 & 0 & Myalgia & 17.1 & 0 & Vision disorder & 18 & 0 & Elevated ALT & 23 & 4 & Edema & 25.2 & 2.1 \\
\hline & $\begin{array}{c}\text { Decreased } \\
\text { appetite }\end{array}$ & 35.1 & 2.3 & $\begin{array}{c}\text { Decreased } \\
\text { appetite }\end{array}$ & 18.5 & 0 & Nausea & 16.4 & 0.7 & Mood effects & 16 & 1 & Pneumonia & 10 & 5 & Anemia & 21.7 & 0.7 \\
\hline
\end{tabular}




\section{Combination Therapy with Angiogenesis Inhibitors and ALK-TKIs}

Angiogenesis inhibitors prevent tumor growth by blocking the signals that promote tumor angiogenesis. There are no clinical trials evaluating the efficacy of angiogenesis inhibitors monotherapy in ALK-rearranged NSCLC. The efficacy of ramucirumab plus erlotinib in EGFR-mutated advanced NSCLC has been reported [50]. Similarly, combination therapy with angiogenesis inhibitors and ALK-TKIs has been studied. A single-arm, prospective observational study investigating the efficacy and safety of bevacizumab plus crizotinib in ALK/ROS-1/c-MET-positive advanced NSCLC has been reported [51]. Patients received crizotinib (250 $\mathrm{mg}$ twice daily) and bevacizumab $(7.5 \mathrm{mg} / \mathrm{kg}$ every 3 weeks) until disease progression or intolerable toxicity or death. The primary endpoint was $\mathrm{mPFS}$, and the secondary endpoints were DOR, ORR, disease control rate (DCR), and safety. In 12 patients with ALK-rearranged NSCLC, mPFS was 13.9 months, and median DOR was 14.8 months. Median OS was NR, and the 3-year survival rate was $79.5 \%$. Of the 12 patients, the best overall response was PR in seven and SD in five. ORR and DCR were $58.3 \%$ and $100 \%$, respectively. The most common adverse events were fatigue $(28.6 \%)$ and rash $(21.4 \%)$. Other adverse events reported were nausea $(14.3 \%)$, vomiting $(7.1 \%)$, edema $(7.1 \%)$, and pain $(7.1 \%)$. Most adverse events $(86.7 \%)$ were grade $1-2$, but two patients had grade 3 or 4 elevations in aminotransferases, and both discontinued treatment. In addition, one patient reported grade 1 hemoptysis, and treatment was discontinued. No interstitial lung disease, active bleeding, hypertension, or treatment-related death occurred. Though this study initially planned to enroll 30 or more patients, however, during the enrollment, second-generation ALK inhibitors were approved as first-line treatment, which made the enrollment difficult, and the sample size was small. However, several other combination therapies with angiogenesis inhibitors and ALK-TKIs are also ongoing (NCT:03779191, NCT:02521051: bevacizumab plus alectinib), (NCT:04227028: bevacizumab plus brigatinib), (NCT:04837716: carboplatin, pemetrexed, bevacizumab plus ensartinib).

\section{Immune Checkpoint Inhibitor}

An immune checkpoint inhibitor (IO) that targets programmed cell death-1 (PD-1), programmed cell death ligand-1 (PD-L1), and CTLA-4 is an important therapeutic agent for NSCLC. The presence of EML4-ALK is associated with increased PD-L1 expression by activating the PI3K-AKT and MEK-ERK pathways [52]. Therefore, treatment of ALKrearranged NSCLC with immune checkpoint inhibitors is expected to be an effective therapeutic strategy. However, IO has been reported to lack efficacy in NSCLC with oncogenic driver mutations, such as EGFR and ALK. In a single-center retrospective study evaluating NSCLC patients with EGFR-mutant $(n=22)$ or ALK-rearranged $(n=6)$ NSCLC treated with IO, objective response was observed in only one patient with EGFR mutation and ORR in patients with ALK-rearrangement was $0 \%$, in contrast to 7 of 30 patients (23.3\%) with EGFR wild type or ALK-negative/unknown ( $p=0.053)$ [53]. Another multicenter retrospective study reported an ORR of $0 \%$, mPFS of 2.5 months (95\% CI: $1.5-3.7$ ), and mOS of 17.0 months (95\% CI: 3.6-NR) for 23 NSCLC patients with ALK-rearrangement treated with IO monotherapy [54]. In a retrospective real-world study of 83 patients (of these, 74 patients received IO as monotherapy) with ALK-rearranged NSCLC who received IO from a multicenter electronic medical record-derived database, the mPFS of patients who received IO before ALK-TKI was 3.9 months, and that of patients who received IO after ALK-TKI was 1.5 months [55]. CheckMate 057 [56] and KEYNOTE-010 [57] are prospective clinical trials treating NSCLC patients with IO, including ALK-rearranged NSCLC patients. However, due to the small number of patients in both trials, outcomes for the ALK-positive cohort have not been reported. Combination therapy with ALK-TKIs and IO has been evaluated in several trials, but many trials have resulted in poor efficacy and increased toxicity. Group E of the phase I/II CheckMate 370 evaluated the safety of the combination of nivolumab ( $240 \mathrm{mg}$ once every two weeks) and crizotinib (250 $\mathrm{mg}$ twice daily) as first-line treatment for previously untreated ALK-rearranged advanced NSCLC patients. Of the 13 patients, 5 (38\%) developed severe hepatotoxicity and discontinued the 
combination therapy, and 2 of the 5 patients died. ORR was reported to be $38 \%$ [58]. In the phase Ib study [59] of pembrolizumab plus crizotinib for previously untreated ALKrearranged advanced NSCLC, one of the first two patients enrolled at dose level 0 (crizotinib $250 \mathrm{mg}$ twice daily and pembrolizumab $200 \mathrm{mg}$ every 3 weeks) required discontinuation of pembrolizumab due to grade 3 liver toxicity, and one died of grade 4 pneumonia induced by pembrolizumab. At dose level -1 (3 weeks of crizotinib monotherapy $250 \mathrm{mg}$ twice daily, followed by crizotinib $250 \mathrm{mg}$ twice daily, with the addition of pembrolizumab $200 \mathrm{mg}$ every 3 weeks), two of the seven patients required pembrolizumab discontinuation and crizotinib discontinuation/reduction due to liver toxicity. This trial was terminated early in the dose-finding phase due to the severe adverse events identified. The phase Ib study evaluated nivolumab ( $3 \mathrm{mg} / \mathrm{kg}$ every 2 weeks) in combination with ceritinib ( $n=14: 450 \mathrm{mg} /$ day or $n=22: 300 \mathrm{mg} /$ day) in 36 patients with previously treated or untreated stage IIIB/IV ALK-rearranged NSCLC [60]. In the dose-escalation study, ORR for patients without prior treatment with ALK-TKI was 83\% (95\% CI: 35.9-99.6) in the $450 \mathrm{mg} /$ day ceritinib group and 60\% (95\% CI: 26.2-87.8) in the $300 \mathrm{mg} /$ day ceritinib group, and ORR for patients with previous treatment with ALK-TKI was 50\% (95\% CI: 15.7-84.3) in the $450 \mathrm{mg} /$ day group and 25\% (95\% CI: 5.5-57.2) in the $300 \mathrm{mg} /$ day group. Elevated alanine aminotransferase level (25\%), elevated gamma-glutamyl transferase level $(22 \%)$, elevated amylase level (14\%), elevated lipase level (11\%), and maculopapular rash $(11 \%)$ were reported to be common grade 3-4 adverse events. The protocol had to be changed for toxicity management, and eventually, the registration was terminated. A phase I trial of erlotinib or crizotinib in combination with the CTLA-4 inhibitor ipilimumab was conducted in patients with EGFR-mutant or ALK-rearranged NSCLC [61]. Median PFS for the three patients with ALK-rearranged NSCLC was 24.1 months. One of the three patients developed dropsy, and one developed grade 2 pneumonia, and the trial was terminated early. Trials of alectinib plus atezolizumab (NCT:02013219) have been completed, and results are awaited. Two clinical trials of combination therapy of platinumdoublet with $\mathrm{IO}(+/$ - angiogenesis inhibitor) for EGFR-mutant/ALK-rearranged NSCLC are ongoing (NCT:04042558: platinum-pemetrexed-atezolizumab +/ - bevacizumab), along with the trial of (NCT:03991403: atezolizumab + bevacizumab + carboplatin + paclitaxel). The results of IO monotherapy and the combination of IO + TKI are summarized in Tables 5 and 6, respectively.

Table 5. Results of a retrospective study of IO monotherapy.

\begin{tabular}{ccccccc}
\hline Study Design & Treatment Line & Patients (n) & ORR (\%) & mPFS (Months) & mOS (Months) & Ref \\
\hline retrospective & $\begin{array}{c}\text { prior lines: } \\
\text { median 3 (0-8) }\end{array}$ & 6 & 0 & NA & NA & [53] \\
\hline retrospective & NA & 23 & 0 & $2.5(95 \%$ CI: $1.5-3.7)$ & 17.0 (95\% CI: 3.6-NR) & [54] \\
\hline retrospective & $\begin{array}{c}\text { 1st:16 }(19.2 \%), \\
\text { 2nd:25 (30.1\%), } \\
\geq 3 \text { rd:42 (50.6\%) }\end{array}$ & $\begin{array}{c}83(\mathrm{IO} \\
\text { monotherapy:74) }\end{array}$ & NA & $\begin{array}{c}\text { before TKI }(n=42): 3.9 \mathrm{~m} \\
\text { after TKI }(n=41): 1.5 \mathrm{~m}\end{array}$ & NA & {$[55]$} \\
\hline
\end{tabular}


Table 6. Results of clinical trials of IO + TKI combination therapy.

\begin{tabular}{|c|c|c|c|c|c|c|c|c|}
\hline Phases & IO & $\begin{array}{l}\text { Treatment } \\
\text { Line }\end{array}$ & Patients (n) & ORR (\%) & $\begin{array}{c}\text { mPFS } \\
\text { (Months) }\end{array}$ & $\mathrm{AE} \geq$ Grade3 (\%) & Status & Ref \\
\hline $\mathrm{I} / \mathrm{II}$ & $\underset{\text { crizotinib }}{\text { nivolumab }}+$ & first & 13 & 38 & NA & 62 & Completed & [58] \\
\hline \multirow{2}{*}{$\mathrm{Ib}$} & \multirow{2}{*}{$\begin{array}{c}\text { pembrolizumab } \\
\text { crizotinib }\end{array}$} & first & dose level 0:2 & 50 & NA & 100 & \multirow{2}{*}{ Terminated } & \multirow{2}{*}{ [59] } \\
\hline & & & dose level $-1: 7$ & 57 & NA & 29 & & \\
\hline \multirow{4}{*}{$\mathrm{Ib}$} & \multirow{2}{*}{$\begin{array}{c}\text { nivolumab + } \\
\text { ceritinib (450 mg) }\end{array}$} & $\begin{array}{l}\text { ALK-TKI } \\
\text { naïve }\end{array}$ & 6 & $\begin{array}{l}83 \text { (95\% CI: } \\
35.9-99.6)\end{array}$ & $\begin{array}{c}\text { NR (95\% CI: } \\
1.8-\mathrm{NE})\end{array}$ & \multirow{2}{*}{93} & \multirow{4}{*}{$\begin{array}{l}\text { Active, not } \\
\text { recruiting }\end{array}$} & \multirow{4}{*}{ [60] } \\
\hline & & $\begin{array}{l}\text { ALK-TKI } \\
\text { pretreated }\end{array}$ & 8 & $\begin{array}{l}50 \text { (95\% CI: } \\
15.7-84.3)\end{array}$ & $\begin{array}{c}6.4 \text { (95\% CI: } \\
0.8-13.7)\end{array}$ & & & \\
\hline & \multirow{2}{*}{$\begin{array}{c}\text { nivolumab + } \\
\text { ceritinib (300 mg) }\end{array}$} & $\begin{array}{l}\text { ALK-TKI } \\
\text { naïve }\end{array}$ & 10 & $\begin{array}{l}60 \text { (95\% CI: } \\
26.2-87.8)\end{array}$ & $\begin{array}{c}\text { NR (95\% CI: } \\
1.9-\mathrm{NE})\end{array}$ & \multirow{2}{*}{82} & & \\
\hline & & $\begin{array}{l}\text { ALK-TKI } \\
\text { pretreated }\end{array}$ & 12 & $\begin{array}{c}25 \text { (95\% CI: } \\
5.5-57.2)\end{array}$ & $\begin{array}{c}3.7 \text { (95\% CI: } \\
1.8-\mathrm{NE})\end{array}$ & & & \\
\hline
\end{tabular}

\section{Chemotherapy}

In a previously reported study, pemetrexed has been reported to be effective for ALKrearranged NSCLC. In the PROFILE 1007 study, median PFS in the chemotherapy arm was 4.2 months in the pemetrexed arm and 2.6 months in the docetaxel arm, suggesting that pemetrexed may be more effective than docetaxel. In addition, two retrospective studies showed that pemetrexed prolongs PFS in ALK-rearranged NSCLC. In a retrospective study of 89 advanced-NSCLC patients (ALK-positive: 19, EGFR-mutant: 12, KRAS-mutant: 21, and wild type: 37), mPFS was reported as 9 months (95\% CI: 3-12) in the ALK-positive, 5.5 months (95\% CI: 1-9) in the EGFR mutant, 7 months (95\% CI: 1.5-10) in the KRAS mutant, and 4 months (95\% CI: 3-5) in the wild type. In the multivariate analysis in this study, ALK was the only driver mutation associated with prolonged PFS in the chemotherapy regimen, including pemetrexed (HR: 0.36 (95\% CI: 0.17-0.73), $p=0.0051$ ) [62]. A retrospective study of 95 patients with advanced NSCLC (ALK-positive: 43, EGFR-mutant: 15, wild-type: 37) reported the efficacy of pemetrexed [63]. ORR was 46.7\% in ALK-positive, 16.2\% in the EGFR mutant, and $4.7 \%$ in the KRAS mutant. Time to progression was 9.2 months in the ALK-positive, 1.4 months in the EGFR mutant, and 2.9 months in the KRAS mutant, regardless of treatment line. ALK-positive was shown to be a significant predictor of ORR (HR: 0.07 (95\% CI: 0.01-0.32), $p=0.001$ ) and time to progression (HR: 0.44 (95\% CI: $0.24-0.80), p=0.007)$. Pemetrexed is an important therapeutic agent for ALK-rearranged NSCLC that is not responsive to ALK-TKIs or cannot tolerate adverse events. The efficacy of combination therapy with EGFR-TKI and platinum doublet therapy for EGFR-mutant NSCLC has been reported in two phase III trials [64,65]. Similarly, the combination of pemetrexed and ALK-TKI is well tolerated; it may improve PFS and OS. The phase II trial to evaluate the efficacy of combination therapy of platinum doublet and ALK-TKI in ALK-rearranged NSCLC is ongoing in Japan (jRCTs041210103). Recent and ongoing clinical trials are summarized in Table 7.

Table 7. Recent and ongoing clinical trials.

\begin{tabular}{lcccc}
\hline & Interventions & Phases & Enrollment & Status \\
\hline & Combination therapy with angiogenesis inhibitors and ALK-TKI & & \\
\hline NCT:03779191 & Alectinib + Bevacizumab & 2 & 40 & Recruiting \\
\hline NCT:02521051 & Alectinib + Bevacizumab & $1 / 2$ & 43 & Recruiting \\
\hline NCT:04227028 & Bevacizumab + Brigatinib & 1 & 31 & Recruiting \\
\hline NCT:04837716 & Bevacizumab + Carboplatin + Ensartinib + Pemetrexed & 1 & 12 & Recruiting \\
\hline & NCT:02013219 & Imune checkpoit inhibitor + ALK-TKI & & \\
\end{tabular}


Table 7. Cont.

\begin{tabular}{ccccc}
\hline & Interventions & Phases & Enrollment & Status \\
\hline & Plutinum doubulet + bevacizumab + Imune checkpoit inhibitor & \\
\hline NCT:04042558 & $\begin{array}{c}\text { Carboplatin + Pemetrexed + Atezolizumab + Bevacizumab } \\
\text { vs. Carboplatin + Pemetrexed + Atezolizumab }\end{array}$ & 2 & 149 & Recruiting \\
\hline NCT:03991403 & $\begin{array}{c}\text { Atezolizumab + Bevacizumab + Carboplatin or Cisplatin + } \\
\text { Pemetrexed or Paclitaxel }\end{array}$ & 3 & 228 & Recruiting \\
\hline jRCTs041210103 & $\begin{array}{c}\text { Chemotherapy + ALK-TKI } \\
\text { Carboplatin + Pemetrexed +Brigatinib }\end{array}$ & 2 & 110 & Recruiting \\
\hline NCT:03535740 & ALK-TKI monotherapy & & 103 & Active, not recruiting \\
\hline NCT:0359686 & Brigatinib & 2 & Recruiting \\
\hline
\end{tabular}

\section{Drug Sensitivity}

Many ALK fusion partners, such as EML4, PM-3/-4, CLTC, LMNA, PRKAR1A, RANBP2, TFG, FN1, and KIF5B, have been identified [66,67]. It is known that the activity of ALK-TKIs varies depending on the partner; for instance, KIF5B-ALK was highly sensitive to ensartinib but was one of the least sensitive fusions to crizotinib and lorlatinib [68]. In addition, several EML4-ALK variants have been reported [69]. The most frequent variant is variant 1, in which exon 13 of EML4 is fused to exon 20 of ALK (E13; A20), and the next most frequent variant is variant $3 a / b$, in which exon $6 a$ or $6 \mathrm{~b}$ of EML4 is fused to exon 20 of ALK (E6a/b; A20). Variant 3 is known to have a shorter mPFS than variant 1 with treatment with crizotinib, alectinib, and ceritinib [70,71]. The ALTA-1L trial evaluated the efficacy of each variant of brigatinib, and similarly, variant 3 showed poorer outcomes compared to variant 1 [43]. The poor prognosis of variant 3 has been attributed to the shorter variant being more stable, accumulating in greater numbers, and interacting better with the cytoskeleton, causing stronger oncogenic signaling, less sensitivity to ALKTKIs, and accelerated migration and metastasis [72-74]. In a retrospective study $(n=129)$, resistance mutations were identified in 10 patients (30\%) in variant 1 and 25 patients $(57 \%)$ in variant $3(p=0.023)$. In particular, the G1202R mutation was detected in 32\% (14/44) in variant 3 compared to $0 \%(0 / 33)$ in variant $1(p<0.001)$. In the same study, an analysis of 12 patients with variant 1 and 17 patients with variant 3 , who received lorlatinib after treatment failure with both crizotinib and at least one second-generation ALK-TKI, reported that patients with variant 3 had a significantly longer PFS than patients with variant 1 (mPFS: 11.0 months vs. 3.3 months, HR: 0.31 (95\% CI: 0.12-0.79), $p=0.011$ ) [75]. The higher drug sensitivity of variant 3 to lorlatinib than variant 1 is because ALK mutations, including the G1202R mutation, which is effective for lorlatinib, are more likely to be associated with variant 3 . The TP53 mutation is a common gene mutation responsible for ALK-TKI resistance [76]. A retrospective study showed that the presence of the TP53 mutation reduced sensitivity to ALK-TKIs, and patients with both variant 3 and the TP53 mutation had a poor prognosis $[77,78]$. The efficacy of the combined use of a proteasome inhibitor with alectinib in ALK-rearranged NSCLC cells with TP53 mutation has been shown in vitro and is expected to be applied to clinical practice [79].

\section{Mechanism of Resistance against ALK-TKI}

The prognosis of ALK-rearranged advanced NSCLC has improved with the contribution of various therapeutic agents; however, cancer cells develop resistance, and patients eventually progress. There are two types of resistance to ALK-TKI-targeted therapy: primary resistance and acquired resistance. 


\subsection{Primary Resistance Mechanisms}

Primary resistance is a rare condition, but according to case reports, primary resistance in patients with ALK-rearranged NSCLC is caused by ALK mutation [80], MYC amplification [81], EGFR mutation [82], a low mutant allele fraction (MAF) of the EML4ALK-rearrangement [83], K-RAS mutations [84], and Bim deletion polymorphism [85].

\subsection{Acquired Resistance Mechanisms}

Mechanisms of acquired resistance are classified into ALK-dependent resistance and ALK-independent resistance.

\subsubsection{ALK-Dependent Resistance Mechanisms}

ALK-dependent resistance mechanisms include ALK amplification and ALK mutation. ALK amplification has been reported as a resistance mechanism to crizotinib, but its incidence is low, and ALK mutation is the problem in most cases [76]. G1202R mutation is the most common ALK resistance mutation to second-generation ALK-TKIs, but the frequency of ALK resistance mutations depends on the ALK-TKI as prior therapy. A study reported the frequency of ALK mutations by performing biopsies after developing resistance to ALK-TKIs [76]. The common secondary ALK mutations were G1202R (21\%), F1174 C/L (17\%), and C1156Y (8\%) after ceritinib; G1202R (29\%), I1171T/S (12\%), V11180L (6\%), and L1196M (6\%) after alectinib; and G1202R (43\%), E1210K (29\%), D1203N (14\%), and S1206Y /C (14\%) after brigatinib, respectively. Furthermore, this study presented in vitro IC50 values for ALK-TKIs regarding the different mutations. For instance, IC50 of alectinib for I1171T/S is $>50 /<200 \mathrm{nM}$, while the IC50 of ceritinib and brigatinib is reported to be $<50$. Therefore, subsequent treatment with other ALK-TKIs may be effective depending on ALK resistance mutations. The third-generation ALK-TKI, lorlatinib, has the broadest spectrum for single ALK resistance mutation, including the G1202R mutation. The efficacy of lorlatinib after treatment with a second-generation ALK-TKI was analyzed in 198 patients enrolled in the phase II study, and the prognosis was indicated to be different depending on whether the ALK mutation was the mechanism of resistance to previous therapy. ORR and PFS were 69\% and 11.0 months, respectively, in the cohort in which ALK mutations were detected by tissue genotyping, while ORR and mPFS were $27 \%$ and 5.4 months in the ALK mutation-negative cohort [86]. The compound ALK mutation (for instance, G1269A + I1171S/C1156, G1202R + L1196M/F1174L, and L1196M + D1203N), which is the main cause of lorlatinib resistance, is the most clinically important major unmet need [87]. The fourth-generation ALK-TKIs are currently considered the most promising treatment for compound ALK mutation. Two fourth-generation ALK TKIs (TPX-0131 and NVL-655) are under development [88-91]. Both TPX-0131 and NVL-655 can inhibit acquired compound ALK mutations in addition to a wide spectrum of single ALK mutations. A phase I/II clinical trial of TPX-0131 for previously treated ALK-rearranged NSCLC patients $(n=210)$ is currently ongoing (NCT:04849273).

\subsubsection{ALK-Independent Resistance Mechanisms}

ALK-independent resistance mechanisms include the activation of bypass signaling pathways, overexpression of $p$-glycoprotein ( $p$-gp) [92], histological transformation [93], and epithelial-mesenchymal transition (EMT) [94]. The activation of bypass signaling pathways includes EGFR signaling [95,96], amplification of KIT [97], the IGF-1R-IRS-1 pathway [98], MAPK [99], MET amplification [100,101], BRAF V600E mutation [100], activation of the transcriptional co-regulator YAP [102], and HER2-amplification [103]. These can occur during treatment with any ALK-TKI, including lorlatinib, and can lead to resistance to ALK-TKIs. Combination therapy with ALK-TKI and their target drugs in patients with activation of bypass signaling pathways other than ALK may overcome drug resistance; thus, their detection is important $[87,104,105]$. MET amplification is sensitive to crizotinib. The efficacy of combination therapy with alectinib and crizotinib has been reported in patients in whom MET amplification was detected after progression with alectinib [106]. 
EMT is the morphological change in which cell-to-cell contacts are lost, making them more mobile and invasive, and tumor cells acquire a mesenchymal morphology and develop drug resistance. HDAC inhibitors have been reported to overcome this resistance mechanism by reversing EMT in vivo and in vitro [94].

\subsection{Treatment Algorithm for ALK-Rearranged Advanced NSCLC}

To date, five ALK-TKIs have been approved by the FDA. However, there are no definitive opinions or the results of clinical trials on sequencing; thus it is largely a matter of clinician judgment today. According to NCCN guideline 2022, alectinib, brigatinib, and lorlatinib are the preferable first-line ALK-TKIs. Ceritinib has not been directly compared with crizotinib in clinical trials, and gastrointestinal toxicity is an issue, although dosage and dose have been adjusted. Crizotinib has been shown to be inferior to other next-generation ALK-TKIs in systemic and central nervous system effects. When the disease progresses during first-line therapy, the identification of resistance mechanisms by performing tissue/liquid biopsy may help to guide optimal treatment. For example, in the case that EML4-ALK G1202R is the cause of resistance, lorlatinib may be a favorable subsequent therapy, and the fourth-generation ALK-TKIs to be developed in the future are effective for compound ALK mutation. When an EGFR mutation is identified, combination therapy with ALK-TKI and EGFR-TKI may be effective, and crizotinib is a reasonable option for patients with confirmed MET amplification. If the disease has converted to small cell lung cancer, a different chemotherapy regimen is required from those for NSCLC. Figure 2 shows the proposed treatment algorithm for ALK-rearranged advanced NSCLC.

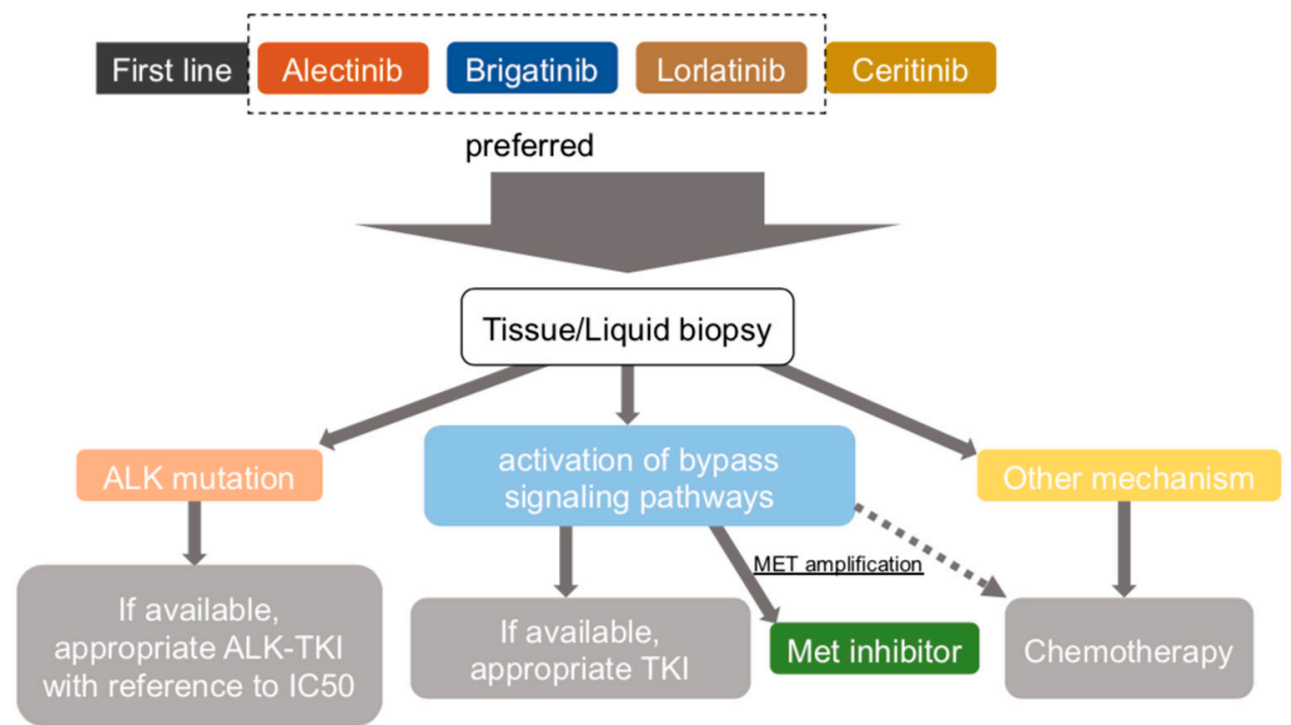

In certain circumstances, crizotinib may be a $1^{\text {st }}$ line treatment option before next-generation ALK-TKIs.

Figure 2. Proposed treatment algorithm for ALK-rearranged advanced NSCLC.

\section{Conclusions}

We described the efficacy and safety of six ALK-TKIs, other chemotherapies, and resistance mechanisms. Currently, clinicians have four options as TKIs for first-line treatment: alectinib, ceritinib, lorlatiniba, and brigatinib. In addition, ensartinib is expected to be approved by the FDA in the future. However, there have been no clinical trials directly comparing second- and third-generation ALK-TKIs, of which TKI is the best, which is an issue that needs to be addressed. Furthermore, there are no definite conclusions regarding the treatment sequence after first-line therapy, and further investigation is required. Combination therapy of ALK-TKIs and angiogenesis inhibitors may become an important treatment regimen, as combination therapy of EGFR-TKIs and angiogenesis inhibitors has shown efficacy for a part of EGFR-mutant NSCLC patients. Furthermore, an important matter for angiogenesis inhibitors is that their efficacy may be enhanced when used in combination 
with IO. The results of clinical trials have shown that IO alone or in combination with IO and platinum doublet chemotherapy is poorly effective, and the combination of TKI and IO was too toxic to continue. The clinical trials of IO in combination with platinum doublet and angiogenesis inhibitors for advanced EGFR/ALK-positive NSCLC are ongoing, and the results are awaited. Resistance against ALK-TKIs is an important issue. Clinical trials of fourth-generation TKI capable of overcoming compound ALK mutation, which is the major mechanism of resistance to lorlatinib, are currently ongoing and are expected to eventually be approved for a treatment option. Moreover, the approach to the ALK-independent resistance mechanism is also important. Especially for patients with activation of bypass signaling pathways, the efficacy of anticancer agents targeting specific genetic mutations in combination with ALK-TKIs has been reported. However, activation of the bypass signaling pathway is rarely identified when the disease progresses in clinical practice, in part because tissue rebiopsy is not often performed. Liquid biopsy is one of the less-invasive methods to identify resistance mechanisms, and non-inferior results compared to tissue samples have been reported. We expect that advances in anticancer therapy and tools for identifying resistance mechanisms, including liquid biopsy, will improve the prognosis of ALK-rearranged NSCLC.

Author Contributions: Writing—original draft preparation, T.F.; writing-review and editing, M.T.; supervision, T.N. and K.K. All authors have read and agreed to the published version of the manuscript.

Funding: M.T. has received grants and personal fees from AstraZeneca K.K., personal fees from Eli Lilly Japan K.K., Taiho Pharmaceutical Co., Ltd., MSD K.K., Nippon Boehringer Ingelheim Co., Ltd., Chugai Pharmaceutical Co., Ltd., Ono Pharmaceutical Co., Ltd., Bristol-Myers Squibb Co., Ltd., and Nippon Kayaku outside this work.

Conflicts of Interest: The authors declare no conflict of interest.

\section{References}

1. Morris, S.W.; Kirstein, M.N.; Valentine, M.B.; Dittmer, K.G.; Shapiro, D.N.; Saltman, D.L.; Look, A.T. Fusion of a kinase gene, ALK, to a nucleolar protein gene, NPM, in non-Hodgkin's lymphoma. Science 1994, 263, 1281-1284. [CrossRef] [PubMed]

2. Yao, S.; Cheng, M.; Zhang, Q.; Wasik, M.; Kelsh, R.; Winkler, C. Anaplastic lymphoma kinase is required for neurogenesis in the developing central nervous system of zebrafish. PLoS ONE 2013, 8, e63757. [CrossRef] [PubMed]

3. Bai, R.Y.; Ouyang, T.; Miething, C.; Morris, S.W.; Peschel, C.; Duyster, J. Nucleophosmin-anaplastic lymphoma kinase associated with anaplastic large-cell lymphoma activates the phosphatidylinositol 3-kinase/Akt antiapoptotic signaling pathway. Blood 2000, 96, 4319-4327. [CrossRef] [PubMed]

4. Kasprzycka, M.; Marzec, M.; Liu, X.; Zhang, Q.; Wasik, M.A. Nucleophosmin/anaplastic lymphoma kinase (NPM/ALK) oncoprotein induces the T regulatory cell phenotype by activating STAT3. Proc. Natl. Acad. Sci. USA 2006, 103, 9964-9969. [CrossRef]

5. Chiarle, R.; Simmons, W.J.; Cai, H.; Dhall, G.; Zamo, A.; Raz, R.; Karras, J.G.; Levy, D.E.; Inghirami, G. Stat3 is required for ALK-mediated lymphomagenesis and provides a possible therapeutic target. Nat. Med. 2005, 11, 623-629. [CrossRef]

6. Soda, M.; Choi, Y.L.; Enomoto, M.; Takada, S.; Yamashita, Y.; Ishikawa, S.; Fujiwara, S.I.; Watanabe, H.; Kurashina, K.; Hatanaka, H.; et al. Identification of the transforming EML4-ALK fusion gene in non-small-cell lung cancer. Nature 2007, 448, 561-566. [CrossRef]

7. Chu, Q.S. Targeting non-small cell lung cancer: Driver mutation beyond epidermal growth factor mutation and anaplastic lymphoma kinase fusion. Ther. Adv. Med. Oncol. 2020, 12, 1758835919895756. [CrossRef]

8. Koivunen, J.P.; Mermel, C.; Zejnullahu, K.; Murphy, C.; Lifshits, E.; Holmes, A.J.; Choi, H.G.; Kim, J.; Chiang, D.; Thomas, R.; et al. EML4-ALK fusion gene and efficacy of an ALK kinase inhibitor in lung cancer. Clin. Cancer Res. 2008, 14, 4275-4283. [CrossRef]

9. Kris, M.G.; Johnson, B.E.; Berry, L.D.; Kwiatkowski, D.J.; Iafrate, A.J.; Wistuba, I.I.; Varella-Garcia, M.; Franklin, W.A.; Aronson, S.L.; Su, P.F.; et al. Using multiplexed assays of oncogenic drivers in lung cancers to select targeted drugs. JAMA 2014, 311, 1998-2006. [CrossRef]

10. Shaw, A.T.; Yeap, B.Y.; Mino-Kenudson, M.; Digumarthy, S.R.; Costa, D.B.; Heist, R.S.; Solomon, B.; Stubbs, H.; Admane, S.; McDermott, U.; et al. Clinical features and outcome of patients with non-small-cell lung cancer who harbor EML4-ALK. J. Clin. Oncol. 2009, 27, 4247-4253. [CrossRef]

11. Rangachari, D.; Yamaguchi, N.; VanderLaan, P.A.; Folch, E.; Mahadevan, A.; Floyd, S.R.; Uhlmann, E.J.; Wong, E.T.; Dahlberg, S.E.; Huberman, M.S.; et al. Brain metastases in patients with EGFR-mutated or ALK-rearranged non-small-cell lung cancers. Lung Cancer 2015, 88, 108-111. [CrossRef] [PubMed] 
12. Ettinger, D.S.; Wood, D.E.; Aggarwal, C.; Aisner, D.L.; Akerley, W.; Bauman, J.R.; Bharat, A.; Bruno, D.S.; Chang, J.Y.; Chirieac, L.R.; et al. NCCN Guidelines Insights: Non-Small Cell Lung Cancer, Version 1.2020. J. Natl. Compr. Canc. Netw. 2019, 17, 1464-1472. [CrossRef] [PubMed]

13. Planchard, D.; Popat, S.; Kerr, K.; Novello, S.; Smit, E.F.; Faivre-Finn, C.; Mok, T.S.; Reck, M.; Van Schil, P.E.; Hellmann, M.D.; et al. Metastatic non-small cell lung cancer: ESMO Clinical Practice Guidelines for diagnosis, treatment and follow-up. Ann. Oncol. Off. J. Eur. Soc. Med. Oncol. 2018, 29 (Suppl. S4), iv192-iv237. [CrossRef] [PubMed]

14. Dziadziuszko, R.; Mok, T.; Peters, S.; Han, J.Y.; Alatorre-Alexander, J.; Leighl, N.; Sriuranpong, V.; Pérol, M.; de Castro Junior, G.; Nadal, E.; et al. Blood First Assay Screening Trial (BFAST) in Treatment-Naive Advanced or Metastatic NSCLC: Initial Results of the Phase 2 ALK-Positive Cohort. J. Thorac. Oncol. 2021, 16, 2040-2050. [CrossRef]

15. Leighl, N.B.; Page, R.D.; Raymond, V.M.; Daniel, D.B.; Divers, S.G.; Reckamp, K.L.; Villalona-Calero, M.A.; Dix, D.; Odegaard, J.I.; Lanman, R.B.; et al. Clinical Utility of Comprehensive Cell-free DNA Analysis to Identify Genomic Biomarkers in Patients with Newly Diagnosed Metastatic Non-small Cell Lung Cancer. Clin. Cancer Res. 2019, 25, 4691-4700. [CrossRef]

16. Esagian, S.M.; Grigoriadou, G.; Nikas, I.P.; Boikou, V.; Sadow, P.M.; Won, J.K.; Economopoulos, K.P. Comparison of liquid-based to tissue-based biopsy analysis by targeted next generation sequencing in advanced non-small cell lung cancer: A comprehensive systematic review. J. Cancer Res. Clin. Oncol. 2020, 146, 2051-2066. [CrossRef]

17. Rolfo, C.; Mack, P.C.; Scagliotti, G.V.; Baas, P.; Barlesi, F.; Bivona, T.G.; Herbst, R.S.; Mok, T.S.; Peled, N.; Pirker, R.; et al. Liquid Biopsy for Advanced Non-Small Cell Lung Cancer (NSCLC): A Statement Paper from the IASLC. J. Thorac. Oncol. 2018, 13, 1248-1268. [CrossRef]

18. Camidge, D.R.; Bang, Y.J.; Kwak, E.L.; Iafrate, A.J.; Varella-Garcia, M.; Fox, S.B.; Riely, G.J.; Solomon, B.; Ou, S.H.I.; Kim, D.W.; et al. Activity and safety of crizotinib in patients with ALK-positive non-small-cell lung cancer: Updated results from a phase 1 study. Lancet. Oncol. 2012, 13, 1011-1019. [CrossRef]

19. Shaw, A.T.; Ou, S.-H.I.; Bang, Y.-J.; Camidge, D.R.; Solomon, B.J.; Salgia, R.; Riely, G.J.; Varella-Garcia, M.; Shapiro, G.I.; Costa, D.B.; et al. Crizotinib in ROS1-rearranged non-small-cell lung cancer. N. Engl. J. Med. 2014, 371, 1963-1971. [CrossRef]

20. Blackhall, F.; Ross Camidge, D.; Shaw, A.T.; Soria, J.C.; Solomon, B.J.; Mok, T.; Hirsh, V.; Jänne, P.A.; Shi, Y.; Yang, P.C.; et al. Final results of the large-scale multinational trial PROFILE 1005: Efficacy and safety of crizotinib in previously treated patients with advanced/metastatic ALK-positive non-small-cell lung cancer. ESMO Open 2017, 2, e000219. [CrossRef]

21. Shaw, A.T.; Kim, D.-W.; Nakagawa, K.; Seto, T.; Crinó, L.; Ahn, M.-J.; De Pas, T.; Besse, B.; Solomon, B.J.; Blackhall, F.; et al Crizotinib versus chemotherapy in advanced ALK-positive lung cancer. N. Engl. J. Med. 2013, 368, 2385-2394. [CrossRef] [PubMed]

22. Solomon, B.J.; Mok, T.; Kim, D.-W.; Wu, Y.-L.; Nakagawa, K.; Mekhail, T.; Felip, E.; Cappuzzo, F.; Paolini, J.; Usari, T.; et al. First-line crizotinib versus chemotherapy in ALK-positive lung cancer. N. Engl. J. Med. 2014, 371, 2167-2177. [CrossRef] [PubMed]

23. Solomon, B.J.; Kim, D.W.; Wu, Y.L.; Nakagawa, K.; Mekhail, T.; Felip, E.; Cappuzzo, F.; Paolini, J.; Usari, T.; Tang, Y.; et al. Final Overall Survival Analysis From a Study Comparing First-Line Crizotinib Versus Chemotherapy in ALK-Mutation-Positive Non-Small-Cell Lung Cancer. J. Clin. Oncol. 2018, 36, 2251-2258. [CrossRef] [PubMed]

24. Metro, G.; Lunardi, G.; Floridi, P.; Pascali, J.P.; Marcomigni, L.; Chiari, R.; Ludovini, V.; Crinò, L.; Gori, S. CSF Concentration of Crizotinib in Two ALK-Positive Non-Small-Cell Lung Cancer Patients with CNS Metastases Deriving Clinical Benefit from Treatment. J. Thorac. Oncol. 2015, 10, e26-e27. [CrossRef]

25. Costa, D.B.; Kobayashi, S.; Pandya, S.S.; Yeo, W.L.; Shen, Z.; Tan, W.; Wilner, K.D. CSF concentration of the anaplastic lymphoma kinase inhibitor crizotinib. J. Clin. Oncol. 2011, 29, e443-e445. [CrossRef]

26. Kim, D.W.; Mehra, R.; Tan, D.S.W.; Felip, E.; Chow, L.Q.M.; Camidge, D.R.; Vansteenkiste, J.; Sharma, S.; De Pas, T.; Riely, G.J.; et al. Activity and safety of ceritinib in patients with ALK-rearranged non-small-cell lung cancer (ASCEND-1): Updated results from the multicentre, open-label, phase 1 trial. Lancet. Oncol. 2016, 17, 452-463. [CrossRef]

27. Crinò, L.; Ahn, M.J.; De Marinis, F.; Groen, H.J.M.; Wakelee, H.; Hida, T.; Mok, T.; Spigel, D.; Felip, E.; Nishio, M.; et al. Multicenter Phase II Study of Whole-Body and Intracranial Activity With Ceritinib in Patients With ALK-Rearranged Non-Small-Cell Lung Cancer Previously Treated With Chemotherapy and Crizotinib: Results From ASCEND-2. J. Clin. Oncol. 2016, 34, $2866-2873$. [CrossRef]

28. Soria, J.C.; Tan, D.S.W.; Chiari, R.; Wu, Y.L.; Paz-Ares, L.; Wolf, J.; Geater, S.L.; Orlov, S.; Cortinovis, D.; Yu, C.J.; et al. Firstline ceritinib versus platinum-based chemotherapy in advanced ALK-rearranged non-small-cell lung cancer (ASCEND-4): A randomised, open-label, phase 3 study. Lancet 2017, 389, 917-929. [CrossRef]

29. Hida, T.; Seto, T.; Horinouchi, H.; Maemondo, M.; Takeda, M.; Hotta, K.; Hirai, F.; Kim, Y.H.; Matsumoto, S.; Ito, M.; et al. Phase II study of ceritinib in alectinib-pretreated patients with anaplastic lymphoma kinase-rearranged metastatic non-small-cell lung cancer in Japan: ASCEND-9. Cancer Sci. 2018, 109, 2863-2872. [CrossRef]

30. Li, J.; Knoll, S.; Bocharova, I.; Tang, W.; Signorovitch, J. Comparative efficacy of first-line ceritinib and crizotinib in advanced or metastatic anaplastic lymphoma kinase-positive non-small cell lung cancer: An adjusted indirect comparison with external controls. Curr. Med. Res. Opin. 2019, 35, 105-111. [CrossRef] [PubMed]

31. Cho, B.C.; Obermannova, R.; Bearz, A.; McKeage, M.; Kim, D.W.; Batra, U.; Borra, G.; Orlov, S.; Kim, S.W.; Geater, S.L.; et al. Efficacy and Safety of Ceritinib (450 mg/d or $600 \mathrm{mg} / \mathrm{d}$ ) With Food Versus 750-mg/d Fasted in Patients With ALK Receptor Tyrosine Kinase (ALK)-Positive NSCLC: Primary Efficacy Results From the ASCEND-8 Study. J. Thorac. Oncol. 2019, 14, 1255-1265. [CrossRef] 
32. Hida, T.; Nokihara, H.; Kondo, M.; Kim, Y.H.; Azuma, K.; Seto, T.; Takiguchi, Y.; Nishio, M.; Yoshioka, H.; Imamura, F.; et al. Alectinib versus crizotinib in patients with ALK-positive non-small-cell lung cancer (J-ALEX): An open-label, randomised phase 3 trial. Lancet 2017, 390, 29-39. [CrossRef]

33. Nakagawa, K.; Hida, T.; Nokihara, H.; Morise, M.; Azuma, K.; Kim, Y.H.; Seto, T.; Takiguchi, Y.; Nishio, M.; Yoshioka, H.; et al. Final progression-free survival results from the J-ALEX study of alectinib versus crizotinib in ALK-positive non-small-cell lung cancer. Lung Cancer 2020, 139, 195-199. [CrossRef]

34. Peters, S.; Camidge, D.R.; Shaw, A.T.; Gadgeel, S.; Ahn, J.S.; Kim, D.-W.; Ou, S.-H.I.; Pérol, M.; Dziadziuszko, R.; Rosell, R.; et al. Alectinib versus Crizotinib in Untreated ALK-Positive Non-Small-Cell Lung Cancer. N. Engl. J. Med. 2017, 377, 829-838. [CrossRef]

35. Camidge, D.R.; Dziadziuszko, R.; Peters, S.; Mok, T.; Noe, J.; Nowicka, M.; Gadgeel, S.M.; Cheema, P.; Pavlakis, N.; de Marinis, F.; et al. Updated Efficacy and Safety Data and Impact of the EML4-ALK Fusion Variant on the Efficacy of Alectinib in Untreated ALK-Positive Advanced Non-Small Cell Lung Cancer in the Global Phase III ALEX Study. J. Thorac. Oncol. 2019, 14, 1233-1243. [CrossRef] [PubMed]

36. Mok, T.; Camidge, D.R.; Gadgeel, S.M.; Rosell, R.; Dziadziuszko, R.; Kim, D.W.; Pérol, M.; Ou, S.H.I.; Ahn, J.S.; Shaw, A.T.; et al. Updated overall survival and final progression-free survival data for patients with treatment-naive advanced ALK-positive non-small-cell lung cancer in the ALEX study. Ann. Oncol. Off. J. Eur. Soc. Med. Oncol. 2020, 31, 1056-1064. [CrossRef] [PubMed]

37. Gadgeel, S.; Peters, S.; Mok, T.; Shaw, A.T.; Kim, D.W.; Ou, S.I.; Pérol, M.; Wrona, A.; Novello, S.; Rosell, R.; et al. Alectinib versus crizotinib in treatment-naive anaplastic lymphoma kinase-positive (ALK+) non-small-cell lung cancer: CNS efficacy results from the ALEX study. Ann. Oncol. Off. J. Eur. Soc. Med. Oncol. 2018, 29, 2214-2222. [CrossRef]

38. Solomon, B.J.; Besse, B.; Bauer, T.M.; Felip, E.; Soo, R.A.; Camidge, D.R.; Chiari, R.; Bearz, A.; Lin, C.C.; Gadgeel, S.M.; et al. Lorlatinib in patients with ALK-positive non-small-cell lung cancer: Results from a global phase 2 study. Lancet. Oncol. 2018, 19, 1654-1667. [CrossRef]

39. Shaw, A.T.; Bauer, T.M.; de Marinis, F.; Felip, E.; Goto, Y.; Liu, G.; Mazieres, J.; Kim, D.-W.; Mok, T.; Polli, A.; et al. First-Line Lorlatinib or Crizotinib in Advanced ALK-Positive Lung Cancer. N. Engl. J. Med. 2020, 383, 2018-2029. [CrossRef]

40. Huber, R.M.; Hansen, K.H.; Paz-Ares Rodríguez, L.; West, H.L.; Reckamp, K.L.; Leighl, N.B.; Tiseo, M.; Smit, E.F.; Kim, D.W.; Gettinger, S.N.; et al. Brigatinib in Crizotinib-Refractory ALK+ NSCLC: 2-Year Follow-up on Systemic and Intracranial Outcomes in the Phase 2 ALTA Trial. J. Thorac. Oncol. 2020, 15, 404-415. [CrossRef]

41. Camidge, D.R.; Kim, H.R.; Ahn, M.-J.; Yang, J.C.-H.; Han, J.-Y.; Lee, J.-S.; Hochmair, M.J.; Li, J.Y.-C.; Chang, G.-C.; Lee, K.H.; et al. Brigatinib versus Crizotinib in ALK-Positive Non-Small-Cell Lung Cancer. N. Engl. J. Med. 2018, 379, 2027-2039. [CrossRef] [PubMed]

42. Camidge, D.R.; Kim, H.R.; Ahn, M.J.; Yang, J.C.H.; Han, J.Y.; Hochmair, M.J.; Lee, K.H.; Delmonte, A.; García Campelo, M.R.; Kim, D.W.; et al. Brigatinib Versus Crizotinib in Advanced ALK Inhibitor-Naive ALK-Positive Non-Small Cell Lung Cancer: Second Interim Analysis of the Phase III ALTA-1L Trial. J. Clin. Oncol. 2020, 38, 3592-3603. [CrossRef]

43. Camidge, D.R.; Kim, H.R.; Ahn, M.J.; Yang, J.C.H.; Han, J.Y.; Hochmair, M.J.; Lee, K.H.; Delmonte, A.; Garcia Campelo, M.R.; Kim, D.W.; et al. Brigatinib Versus Crizotinib in ALK Inhibitor-Naive Advanced ALK-Positive NSCLC: Final Results of Phase 3 ALTA-1L Trial. J. Thorac. Oncol. 2021, 16, 2091-2108. [CrossRef] [PubMed]

44. Lin, M.M.; Pan, X.; Hou, P.; Allen, S.; Baumann, P.; Hochmair, M.J. Treatment duration of brigatinib in patients enrolled in the international expanded access program (EAP). Ann. Oncol. 2019, 30, ii48. [CrossRef]

45. Nishio, M.; Yoshida, T.; Kumagai, T.; Hida, T.; Toyozawa, R.; Shimokawaji, T.; Goto, K.; Nakagawa, K.; Ohe, Y.; Seto, T.; et al. Brigatinib in Japanese Patients With ALK-Positive NSCLC Previously Treated With Alectinib and Other Tyrosine Kinase Inhibitors: Outcomes of the Phase 2 J-ALTA Trial. J. Thorac. Oncol. 2021, 16, 452-463. [CrossRef] [PubMed]

46. Kim, E.S.; Barlesi, F.; Mok, T.; Ahn, M.J.; Shen, J.; Zhang, P.; Ou, S.H.I. ALTA-2: Phase II study of brigatinib in patients with ALK-positive, advanced non-small-cell lung cancer who progressed on alectinib or ceritinib. Future Oncol. 2021, 17, 1709-1719. [CrossRef] [PubMed]

47. Popat, S.; Liu, G.; Lu, S.; Song, G.; Ma, X.; Yang, J.C.-H. Brigatinib vs. alectinib in crizotinib-resistant advanced anaplastic lymphoma kinase-positive non-small-cell lung cancer (ALTA-3). Future Oncol. 2021, 17, 4237-4247. [CrossRef]

48. Horn, L.; Infante, J.R.; Reckamp, K.L.; Blumenschein, G.R.; Leal, T.A.; Waqar, S.N.; Gitlitz, B.J.; Sanborn, R.E.; Whisenant, J.G.; Du, L.; et al. Ensartinib (X-396) in ALK-Positive Non-Small Cell Lung Cancer: Results from a First-in-Human Phase I/II, Multicenter Study. Clin. Cancer Res. 2018, 24, 2771-2779. [CrossRef]

49. Horn, L.; Wang, Z.; Wu, G.; Poddubskaya, E.; Mok, T.; Reck, M.; Wakelee, H.; Chiappori, A.A.; Lee, D.H.; Breder, V.; et al. Ensartinib vs. Crizotinib for Patients With Anaplastic Lymphoma Kinase-Positive Non-Small Cell Lung Cancer: A Randomized Clinical Trial. JAMA Oncol. 2021, 7, 1617-1625. [CrossRef]

50. Nakagawa, K.; Garon, E.B.; Seto, T.; Nishio, M.; Ponce Aix, S.; Paz-Ares, L.; Chiu, C.H.; Park, K.; Novello, S.; Nadal, E.; et al. Ramucirumab plus erlotinib in patients with untreated, EGFR-mutated, advanced non-small-cell lung cancer (RELAY): A randomised, double-blind, placebo-controlled, phase 3 trial. Lancet Oncol. 2019, 20, 1655-1669. [CrossRef]

51. Huang, Z.; Xiong, Q.; Cui, Z.; Tao, H.; Zhang, S.; Wang, L.; Cui, P.; Chen, S.; Huang, D.; Yang, B.; et al. Efficacy and safety of crizotinib plus bevacizumab in ALK/ROS-1/c-MET positive non-small cell lung cancer: An open-label, single-arm, prospective observational study. Am. J. Transl. Res. 2021, 13, 1526-1534. [PubMed] 
52. Ota, K.; Azuma, K.; Kawahara, A.; Hattori, S.; Iwama, E.; Tanizaki, J.; Harada, T.; Matsumoto, K.; Takayama, K.; Takamori, S.; et al. Induction of PD-L1 Expression by the EML4-ALK Oncoprotein and Downstream Signaling Pathways in Non-Small Cell Lung Cancer. Clin. Cancer Res. 2015, 21, 4014-4021. [CrossRef] [PubMed]

53. Gainor, J.F.; Shaw, A.T.; Sequist, L.V.; Fu, X.; Azzoli, C.G.; Piotrowska, Z.; Huynh, T.G.; Zhao, L.; Fulton, L.; Schultz, K.R.; et al. EGFR Mutations and ALK Rearrangements Are Associated with Low Response Rates to PD-1 Pathway Blockade in Non-Small Cell Lung Cancer: A Retrospective Analysis. Clin. Cancer Res. 2016, 22, 4585-4593. [CrossRef] [PubMed]

54. Mazieres, J.; Drilon, A.; Lusque, A.; Mhanna, L.; Cortot, A.B.; Mezquita, L.; Thai, A.A.; Mascaux, C.; Couraud, S.; Veillon, R.; et al. Immune checkpoint inhibitors for patients with advanced lung cancer and oncogenic driver alterations: Results from the IMMUNOTARGET registry. Ann. Oncol. Off. J. Eur. Soc. Med. Oncol. 2019, 30, 1321-1328. [CrossRef]

55. Jahanzeb, M.; Lin, H.M.; Pan, X.; Yin, Y.; Baumann, P.; Langer, C.J. Immunotherapy Treatment Patterns and Outcomes Among ALK-Positive Patients With Non-Small-Cell Lung Cancer. Clin. Lung Cancer 2021, 22, 49-57. [CrossRef]

56. Borghaei, H.; Paz-Ares, L.; Horn, L.; Spigel, D.R.; Steins, M.; Ready, N.E.; Chow, L.Q.; Vokes, E.E.; Felip, E.; Holgado, E.; et al. Nivolumab versus Docetaxel in Advanced Nonsquamous Non-Small-Cell Lung Cancer. N. Engl. J. Med. 2015, 373, 1627-1639. [CrossRef]

57. Herbst, R.S.; Baas, P.; Kim, D.W.; Felip, E.; Pérez-Gracia, J.L.; Han, J.Y.; Molina, J.; Kim, J.H.; Arvis, C.D.; Ahn, M.J.; et al. Pembrolizumab versus docetaxel for previously treated, PD-L1-positive, advanced non-small-cell lung cancer (KEYNOTE-010): A randomised controlled trial. Lancet 2016, 387, 1540-1550. [CrossRef]

58. Spigel, D.R.; Reynolds, C.; Waterhouse, D.; Garon, E.B.; Chandler, J.; Babu, S.; Thurmes, P.; Spira, A.; Jotte, R.; Zhu, J.; et al. Phase $1 / 2$ Study of the Safety and Tolerability of Nivolumab Plus Crizotinib for the First-Line Treatment of Anaplastic Lymphoma Kinase Translocation-Positive Advanced Non-Small Cell Lung Cancer (CheckMate 370). J. Thorac. Oncol. 2018, 13, 682-688. [CrossRef]

59. Patel, S.P.; Pakkala, S.; Pennell, N.A.; Reckamp, K.L.; Lanzalone, S.; Polli, A.; Tarazi, J.; Robert-Vizcarrondo, F. Phase Ib Study of Crizotinib plus Pembrolizumab in Patients with Previously Untreated Advanced Non-Small Cell Lung Cancer with ALK Translocation. Oncologist 2020, 25, 562. [CrossRef]

60. Felip, E.; de Braud, F.G.; Maur, M.; Loong, H.H.; Shaw, A.T.; Vansteenkiste, J.F.; John, T.; Liu, G.; Lolkema, M.P.; Selvaggi, G.; et al. Ceritinib plus Nivolumab in Patients with Advanced ALK-Rearranged Non-Small Cell Lung Cancer: Results of an Open-Label, Multicenter, Phase 1B Study. J. Thorac. Oncol. 2020, 15, 392-403. [CrossRef]

61. Chalmers, A.W.; Patel, S.; Boucher, K.; Cannon, L.; Esplin, M.; Luckart, J.; Graves, N.; Van Duren, T.; Akerley, W. Phase I Trial of Targeted EGFR or ALK Therapy with Ipilimumab in Metastatic NSCLC with Long-Term Follow-Up. Target. Oncol. 2019, 14, 417-421. [CrossRef] [PubMed]

62. Camidge, D.R.; Kono, S.A.; Lu, X.; Okuyama, S.; Barón, A.E.; Oton, A.B.; Davies, A.M.; Varella-Garcia, M.; Franklin, W.; Doebele, R.C. Anaplastic lymphoma kinase gene rearrangements in non-small cell lung cancer are associated with prolonged progression-free survival on pemetrexed. J. Thorac. Oncol. 2011, 6, 774-780. [CrossRef] [PubMed]

63. Lee, J.O.; Kim, T.M.; Lee, S.H.; Kim, D.W.; Kim, S.; Jeon, Y.K.; Chung, D.H.; Kim, W.H.; Kim, Y.T.; Yang, S.C.; et al. Anaplastic lymphoma kinase translocation: A predictive biomarker of pemetrexed in patients with non-small cell lung cancer. J. Thorac. Oncol. 2011, 6, 1474-1480. [CrossRef]

64. Hosomi, Y.; Morita, S.; Sugawara, S.; Kato, T.; Fukuhara, T.; Gemma, A.; Takahashi, K.; Fujita, Y.; Harada, T.; Minato, K.; et al. Gefitinib Alone Versus Gefitinib Plus Chemotherapy for Non-Small-Cell Lung Cancer With Mutated Epidermal Growth Factor Receptor: NEJ009 Study. J. Clin. Oncol. 2020, 38, 115-123. [CrossRef]

65. Noronha, V.; Patil, V.M.; Joshi, A.; Menon, N.; Chougule, A.; Mahajan, A.; Janu, A.; Purandare, N.; Kumar, R.; More, S.; et al. Gefitinib Versus Gefitinib Plus Pemetrexed and Carboplatin Chemotherapy in EGFR-Mutated Lung Cancer. J. Clin. Oncol. 2020, 38, 124-136. [CrossRef] [PubMed]

66. Lovly, C.M.; Gupta, A.; Lipson, D.; Otto, G.; Brennan, T.; Chung, C.T.; Borinstein, S.C.; Ross, J.S.; Stephens, P.J.; Miller, V.A.; et al. Inflammatory myofibroblastic tumors harbor multiple potentially actionable kinase fusions. Cancer Discov. 2014, 4, 889-895. [CrossRef] [PubMed]

67. Shaw, A.T.; Hsu, P.P.; Awad, M.M.; Engelman, J.A. Tyrosine kinase gene rearrangements in epithelial malignancies. Nat. Rev. Cancer 2013, 13, 772-787. [CrossRef]

68. Childress, M.A.; Himmelberg, S.M.; Chen, H.; Deng, W.; Davies, M.A.; Lovly, C.M. ALK Fusion Partners Impact Response to ALK Inhibition: Differential Effects on Sensitivity, Cellular Phenotypes, and Biochemical Properties. Mol. Cancer Res. 2018, 16, 1724-1736. [CrossRef]

69. Sasaki, T.; Rodig, S.J.; Chirieac, L.R.; Jänne, P.A. The biology and treatment of EML4-ALK non-small cell lung cancer. Eur. J. Cancer 2010, 46, 1773-1780. [CrossRef]

70. Woo, C.G.; Seo, S.; Kim, S.W.; Jang, S.J.; Park, K.S.; Song, J.Y.; Lee, B.; Richards, M.W.; Bayliss, R.; Lee, D.H.; et al. Differential protein stability and clinical responses of EML4-ALK fusion variants to various ALK inhibitors in advanced ALK-rearranged non-small cell lung cancer. Ann. Oncol. Off. J. Eur. Soc. Med. Oncol. 2017, 28, 791-797. [CrossRef]

71. Christopoulos, P.; Endris, V.; Bozorgmehr, F.; Elsayed, M.; Kirchner, M.; Ristau, J.; Buchhalter, I.; Penzel, R.; Herth, F.J.; Heussel, C.P.; et al. EML4-ALK fusion variant V3 is a high-risk feature conferring accelerated metastatic spread, early treatment failure and worse overall survival in ALK + non-small cell lung cancer. Int. J. Cancer 2018, 142, 2589-2598. [CrossRef] [PubMed] 
72. Sabir, S.R.; Yeoh, S.; Jackson, G.; Bayliss, R. EML4-ALK Variants: Biological and Molecular Properties, and the Implications for Patients. Cancers 2017, 9, 118. [CrossRef]

73. Noh, K.W.; Lee, M.S.; Lee, S.E.; Song, J.Y.; Shin, H.T.; Kim, Y.J.; Oh, D.Y.; Jung, K.; Sung, M.; Kim, M.; et al. Molecular breakdown: A comprehensive view of anaplastic lymphoma kinase (ALK)-rearranged non-small cell lung cancer. J. Pathol. 2017, 243, 307-319. [CrossRef] [PubMed]

74. O'Regan, L.; Barone, G.; Adib, R.; Woo, C.G.; Jeong, H.J.; Richardson, E.L.; Richards, M.W.; Muller, P.A.J.; Collis, S.J.; Fennell, D.A.; et al. EML4-ALK V3 oncogenic fusion proteins promote microtubule stabilization and accelerated migration through NEK9 and NEK7. J. Cell Sci. 2020, 133, jcs241505. [CrossRef] [PubMed]

75. Lin, J.J.; Zhu, V.W.; Yoda, S.; Yeap, B.Y.; Schrock, A.B.; Dagogo-Jack, I.; Jessop, N.A.; Jiang, G.Y.; Le, L.P.; Gowen, K.; et al. Impact of EML4-ALK Variant on Resistance Mechanisms and Clinical Outcomes in ALK-Positive Lung Cancer. J. Clin. Oncol. 2018, 36, 1199-1206. [CrossRef] [PubMed]

76. Gainor, J.F.; Dardaei, L.; Yoda, S.; Friboulet, L.; Leshchiner, I.; Katayama, R.; Dagogo-Jack, I.; Gadgeel, S.; Schultz, K.; Singh, M.; et al. Molecular Mechanisms of Resistance to First- and Second-Generation ALK Inhibitors in ALK-Rearranged Lung Cancer. Cancer Discov. 2016, 6, 1118-1133. [CrossRef]

77. Kron, A.; Alidousty, C.; Scheffler, M.; Merkelbach-Bruse, S.; Seidel, D.; Riedel, R.; Ihle, M.A.; Michels, S.; Nogova, L.; Fassunke, J.; et al. Impact of TP53 mutation status on systemic treatment outcome in ALK-rearranged non-small-cell lung cancer. Ann. Oncol. Off. J. Eur. Soc. Med. Oncol. 2018, 29, 2068-2075. [CrossRef]

78. Christopoulos, P.; Kirchner, M.; Bozorgmehr, F.; Endris, V.; Elsayed, M.; Budczies, J.; Ristau, J.; Penzel, R.; Herth, F.J.; Heussel, C.P.; et al. Identification of a highly lethal V3 + TP53 + subset in ALK + lung adenocarcinoma. Int. J. Cancer 2019, 144, 190-199. [CrossRef]

79. Tanimoto, A.; Matsumoto, S.; Takeuchi, S.; Arai, S.; Fukuda, K.; Nishiyama, A.; Yoh, K.; Ikeda, T.; Furuya, N.; Nishino, K.; et al. Proteasome Inhibition Overcomes ALK-TKI Resistance in ALK-Rearranged/ TP53-Mutant NSCLC via Noxa Expression. Clin. Cancer Res. 2021, 27, 1410-1420. [CrossRef]

80. Sharma, G.G.; Cortinovis, D.; Agustoni, F.; Arosio, G.; Villa, M.; Cordani, N.; Bidoli, P.; Bisson, W.H.; Pagni, F.; Piazza, R.; et al. A Compound L1196M/G1202R ALK Mutation in a Patient with ALK-Positive Lung Cancer with Acquired Resistance to Brigatinib Also Confers Primary Resistance to Lorlatinib. J. Thorac. Oncol. 2019, 14, e257-e259. [CrossRef]

81. Rihawi, K.; Alfieri, R.; Fiorentino, M.; Fontana, F.; Capizzi, E.; Cavazzoni, A.; Terracciano, M.; La Monica, S.; Ferrarini, A.; Buson, G.; et al. MYC Amplification as a Potential Mechanism of Primary Resistance to Crizotinib in ALK-Rearranged Non-Small Cell Lung Cancer: A Brief Report. Transl. Oncol. 2019, 12, 116-121. [CrossRef]

82. Long, Y.; Zhang, K.; Li, Y.; Yu, M.; Zhu, J.; Huang, M. Durable complete response after afatinib and crizotinib in an advanced non-small cell lung cancer patient with EGFR L861Q mutation and acquired MET amplification: A case report. Ann. Palliat. Med. 2020, 9, 3609-3613. [CrossRef] [PubMed]

83. Zhang, L.; Li, Y.; Zhang, S.; Gao, C.; Nie, K.; Ji, Y. Primary resistance to crizotinib treatment in a non-small cell lung cancer patient with an EML4-ALK rearrangement: A case report. Cancer Biol. Med. 2018, 15, 178-181. [CrossRef] [PubMed]

84. Mengoli, M.C.; Barbieri, F.; Bertolini, F.; Tiseo, M.; Rossi, G. K-RAS mutations indicating primary resistance to crizotinib in ALK-rearranged adenocarcinomas of the lung: Report of two cases and review of the literature. Lung Cancer 2016, 93, 55-58. [CrossRef] [PubMed]

85. Zhang, L.; Jiang, T.; Li, X.; Wang, Y.; Zhao, C.; Zhao, S.; Xi, L.; Zhang, S.; Liu, X.; Jia, Y.; et al. Clinical features of Bim deletion polymorphism and its relation with crizotinib primary resistance in Chinese patients with ALK/ROS1 fusion-positive non-small cell lung cancer. Cancer 2017, 123, 2927-2935. [CrossRef] [PubMed]

86. Shaw, A.T.; Solomon, B.J.; Besse, B.; Bauer, T.M.; Lin, C.C.; Soo, R.A.; Riely, G.J.; Ignatius Ou, S.H.; Clancy, J.S.; Li, S.; et al. ALK Resistance Mutations and Efficacy of Lorlatinib in Advanced Anaplastic Lymphoma Kinase-Positive Non-Small-Cell Lung Cancer. J. Clin. Oncol. 2019, 37, 1370-1379. [CrossRef] [PubMed]

87. Recondo, G.; Mezquita, L.; Facchinetti, F.; Planchard, D.; Gazzah, A.; Bigot, L.; Rizvi, A.Z.; Frias, R.L.; Thiery, J.P.; Scoazec, J.Y.; et al. Diverse Resistance Mechanisms to the Third-Generation ALK Inhibitor Lorlatinib in ALK-Rearranged Lung Cancer. Clin. Cancer Res. 2020, 26, 242-255. [CrossRef]

88. Ou, S.H.I.; Nagasaka, M.; Brazel, D.; Hou, Y.; Zhu, V.W. Will the clinical development of 4th-generation "double mutant active" ALK TKIs (TPX-0131 and NVL-655) change the future treatment paradigm of ALK+ NSCLC? Transl. Oncol. $2021,14,101191$. [CrossRef]

89. Cui, J.J.; Rogers, E.; Zhai, D.; Deng, W.; Ung, J.; Nguyen, V.; Zhang, H.; Zhang, X.; Parra, A.; Barrera, M.; et al. Abstract 5226: TPX-0131: A next generation macrocyclic ALK inhibitor that overcomes ALK resistant mutations refractory to current approved ALK inhibitors. Presented at the Annual Meeting of the American Association for Cancer Research 2020, Philadelphia, PA, USA, 27-28 April and 22-24 June 2020. [CrossRef]

90. Murray, B.W.; Zhai, D.; Deng, W.; Zhang, X.; Ung, J.; Nguyen, V.; Zhang, H.; Barrera, M.; Parra, A.; Cowell, J.; et al. TPX-0131, a Potent CNS-penetrant, Next-generation Inhibitor of Wild-type ALK and ALK-resistant Mutations. Mol. Cancer Ther. 2021, 20, 1499-1507. [CrossRef] 
91. Pelish, H.E.; Tangpeerachaikul, A.; Kohl, N.E.; Porter, J.R.; Shair, M.D.; Horan, J.C. Abstract 1468: NUV-655 (NVL-655) is a selective, brain-penetrant ALK inhibitor with antitumor activity against the lorlatinib-resistant G1202R/L1196M compound mutation. Presented at the Annual Meeting of the American Association for Cancer Research 2021, Philadelphia, PA, USA, 10-15 April and 17-21 May 2021. [CrossRef]

92. Katayama, R.; Sakashita, T.; Yanagitani, N.; Ninomiya, H.; Horiike, A.; Friboulet, L.; Gainor, J.F.; Motoi, N.; Dobashi, A.; Sakata, S.; et al. P-glycoprotein Mediates Ceritinib Resistance in Anaplastic Lymphoma Kinase-rearranged Non-small Cell Lung Cancer. EBioMedicine 2015, 3, 54-66. [CrossRef]

93. Cha, Y.J.; Cho, B.C.; Kim, H.R.; Lee, H.J.; Shim, H.S. A Case of ALK-Rearranged Adenocarcinoma with Small Cell Carcinoma-Like Transformation and Resistance to Crizotinib. J. Thorac. Oncol. 2016, 11, e55-e58. [CrossRef] [PubMed]

94. Fukuda, K.; Takeuchi, S.; Arai, S.; Katayama, R.; Nanjo, S.; Tanimoto, A.; Nishiyama, A.; Nakagawa, T.; Taniguchi, H.; Suzuki, T.; et al. Epithelial-to-Mesenchymal Transition Is a Mechanism of ALK Inhibitor Resistance in Lung Cancer Independent of ALK Mutation Status. Cancer Res. 2019, 79, 1658-1670. [CrossRef] [PubMed]

95. Sasaki, T.; Koivunen, J.; Ogino, A.; Yanagita, M.; Nikiforow, S.; Zheng, W.; Lathan, C.; Marcoux, J.P.; Du, J.; Okuda, K.; et al. A novel ALK secondary mutation and EGFR signaling cause resistance to ALK kinase inhibitors. Cancer Res. 2011, 71, 6051-6060. [CrossRef] [PubMed]

96. Miyawaki, M.; Yasuda, H.; Tani, T.; Hamamoto, J.; Arai, D.; Ishioka, K.; Ohgino, K.; Nukaga, S.; Hirano, T.; Kawada, I.; et al. Overcoming EGFR Bypass Signal-Induced Acquired Resistance to ALK Tyrosine Kinase Inhibitors in ALK-Translocated Lung Cancer. Mol. Cancer Res. 2017, 15, 106-114. [CrossRef]

97. Katayama, R.; Shaw, A.T.; Khan, T.M.; Mino-Kenudson, M.; Solomon, B.J.; Halmos, B.; Jessop, N.A.; Wain, J.C.; Yeo, A.T.; Benes, C.; et al. Mechanisms of acquired crizotinib resistance in ALK-rearranged lung Cancers. Sci. Transl. Med. 2012, 4. [CrossRef]

98. Lovly, C.M.; McDonald, N.T.; Chen, H.; Ortiz-Cuaran, S.; Heukamp, L.C.; Yan, Y.; Florin, A.; Ozretić, L.; Lim, D.; Wang, L.; et al. Rationale for co-targeting IGF-1R and ALK in ALK fusion-positive lung cancer. Nat. Med. 2014, 20, 1027-1034. [CrossRef]

99. Crystal, A.S.; Shaw, A.T.; Sequist, L.V.; Friboulet, L.; Niederst, M.J.; Lockerman, E.L.; Frias, R.L.; Gainor, J.F.; Amzallag, A.; Greninger, P.; et al. Patient-derived models of acquired resistance can identify effective drug combinations for cancer. Science 2014, 346, 1480-1486. [CrossRef]

100. Shi, R.; Filho, S.N.M.; Li, M.; Fares, A.; Weiss, J.; Pham, N.A.; Ludkovski, O.; Raghavan, V.; Li, Q.; Ravi, D.; et al. BRAF V600E mutation and MET amplification as resistance pathways of the second-generation anaplastic lymphoma kinase (ALK) inhibitor alectinib in lung cancer. Lung Cancer 2020, 146, 78-85. [CrossRef]

101. Dagogo-Jack, I.; Yoda, S.; Lennerz, J.K.; Langenbucher, A.; Lin, J.J.; Rooney, M.M.; Prutisto-Chang, K.; Oh, A.; Adams, N.A.; Yeap, B.Y.; et al. MET Alterations Are a Recurring and Actionable Resistance Mechanism in ALK-Positive Lung Cancer. Clin. Cancer Res. 2020, 26, 2535-2545. [CrossRef] [PubMed]

102. Yun, M.R.; Choi, H.M.; Lee, Y.W.; Joo, H.S.; Park, C.W.; Choi, J.W.; Kim, D.H.; Kang, H.N.; Pyo, K.; Shin, E.J.; et al. Targeting YAP to overcome acquired resistance to ALK inhibitors in ALK-rearranged lung cancer. EMBO Mol. Med. 2019, 11, e10581. [CrossRef]

103. Tsui, D.C.C.; Aisner, D.; Nijmeh, H.; Bao, L.; Menter, A.; Camidge, D.R. Tumor Shrinkage With Combination of Alectinib and Trastuzumab in a Patient With ALK-Rearranged Non-small Cell Lung Cancer Harboring HER2-Amplification as an Acquired Resistance Mechanism to ALK Inhibitor Therapy. Clin. Lung Cancer 2022, 23, e99-e103. [CrossRef] [PubMed]

104. Arai, S.; Takeuchi, S.; Fukuda, K.; Taniguchi, H.; Nishiyama, A.; Tanimoto, A.; Satouchi, M.; Yamashita, K.; Ohtsubo, K.; Nanjo, S.; et al. Osimertinib Overcomes Alectinib Resistance Caused by Amphiregulin in a Leptomeningeal Carcinomatosis Model of ALK-Rearranged Lung Cancer. J. Thorac. Oncol. 2020, 15, 752-765. [CrossRef] [PubMed]

105. Tsuji, T.; Ozasa, H.; Aoki, W.; Aburaya, S.; Funazo, T.; Furugaki, K.; Yoshimura, Y.; Ajimizu, H.; Okutani, R.; Yasuda, Y.; et al. Alectinib Resistance in ALK-Rearranged Lung Cancer by Dual Salvage Signaling in a Clinically Paired Resistance Model. Mol. Cancer Res. 2019, 17, 212-224. [CrossRef] [PubMed]

106. Ji, J.; Mitra, A.; Camidge, D.R.; Riess, J.W. Early Alectinib Resistance From MET Amplification in ALK-Rearranged NSCLC: Response to Crizotinib with Re-Response to Alectinib and Crizotinib. Clin. Lung Cancer 2021, 22, e851-e855. [CrossRef] 